\title{
Impact of Alternative Skin Contact Procedures on the Aroma Composition of White Wine
}

\author{
D. Bavčar ${ }^{1 *}$, H. Baša Česnik ${ }^{1}$, F. Čuš ${ }^{1}$, A. Vanzo ${ }^{1}$, L. Gašperlin ${ }^{2}$, T. Košmerl ${ }^{2}$
}

(1) Agricultural Institute of Slovenia, Hacquetova 17, SI-1000 Ljubljana, Slovenia

(2) Biotechnical Faculty, University of Ljubljana, Jamnikarjeva 101, SI-1000 Ljubljana, Slovenia

Submitted for publication: September 2010

Accepted for publication: April 2011

Key words: Wine, skin contact, aromatic compounds

\begin{abstract}
Zelen, Ribolla Gialla and Malvasia Istriana, grapes from the Vitis vinifera (L.) varieties, were subjected to four processes involving grape skin contact. Fresh and fruity young wines were produced by adding $6 \%$ or $12 \%$ grape berries, respectively, during alcoholic fermentation, freezing the pomace (Fp) and the freezing whole grapes (Fg). Wine-free volatile aromatic compounds were determined using two extraction techniques coupled to gas chromatography (GC). These aromatic compounds and wine standard chemical parameters were compared to control wines produced without skin contact. Esters, higher alcohols, terpenes, volatile phenols and $\mathrm{C}_{6}$ alcohols proved to be the most important sensorial odorants in wines. Both the content of aromatic compounds and the odour activity values showed some positive effects from skin contact. The freezing of the grapes and addition of $12 \%$ grape berries proved most effective for Zelen and Malvasia Istriana, producing a more intensive fruity and floral odour, a less intensive solvent odour and additional freshness. The same processes resulted only in additional fruitiness or a less intensive solvent odour in Ribolla Gialla while the lowest concentrations of grape derived terpenes were achieved for this variety. The three varieties were most affected by freezing processes. During the sensorial evaluation, the wines that had been subjected to skin contact were generally preferred to the control wines.
\end{abstract}

\section{INTRODUCTION}

Wine aroma is a result of the interaction of the inherent components of grapes during processing, fermentation and aging. With the exception of the Sauvignon cultivar, grapederived aromatic compounds are terpenes, $\mathrm{C}_{13}$ norisoprenoids, benzene derivates and aliphatic alcohols (Sanchez Palomo et al., 2006). Aromatic compounds from grapes can appear later in must and wine as volatile free forms or as odourless, non-volatile glycosides (Gunata et al., 1985).

As only free forms are volatile and therefore detected by our sense of smell, acid and enzymatic hydrolysis of aromatic glycosides have been investigated by different authors (Williams et al., 1981; Gunata et al., 1985; Aryan et al., 1987; Bayonove et al., 1993; Delcroix et al., 1994; Mateo \& Jimenez 2000; Tamborra et al., 2004; Rocha et al., 2005; Sanchez Palomo et al., 2005). According to the quantities of free and glycoside forms of varietal aromatic compounds, grapes and wines can be classified as neutral or aromatic, while glycoside forms are the same for both (Cabrita et al., 2006).

Pre-fermentation practices determine the aromatic characteristics of white wine (Ribéreau Gayon et al., 2006). Maceration or pre-fermentative skin contact of crushed grapes under controlled conditions, the most popular process used to improve the aroma of wine, has been investigated for decades (Arnold \& Nobel, 1979; Versini et al., 1981; Ramey et al., 1986; Marais, 1987; Marais \& Rapp, 1988; Gerbi et al., 1991; Tamborra, 1992; Reynolds et al., 1993; Cabaroglu et al., 1997; Selli et al., 2003; Sanchez Palomo et al., 2006; Rodriguez Bencomo et al., 2008). It is thus known to enhance the presence of free and glycosided forms of volatile compounds derived from grapes in must and wines, since glycoside forms are found mainly in skins (Versini et al., 1981; Ramey et al., 1986; Marais, 1987, Marais \& Rapp, 1988, Gerbi et al., 1991; Tamborra, 1992; Reynolds et al., 1993; Cabaroglu et al., 1997; Selli et al., 2003; Peinado et al., 2004; Sanchez Palomo et al., 2006; Selli et al., 2006). Higher quantities of glycoside forms in must are not always correlated to the amount of free volatile forms in wines (Sanchez Palomo et al., 2007; Rodriguez Bencomo et al., 2008). Because of the different chemical composition of must after maceration, changes in volatile compounds during alcoholic fermentation are commonly observed (Cabaroglu et al., 1997; Seli et al., 2006; Sanchez Palomo et al., 2006, 2007; Rodriguez Bencomo et al., 2008). With the exception of Sauvignon grapes, investigations of skin contact effects are popular primarily for Muscat varieties because of the 
terpenes present in high quantities (Gerbi et al., 1991; Tamborra, 1992; Delcroix et al., 1994; Selli et al., 2003; Sanchez Palomo et al., 2006. Selli et al., 2006).

Following the global popularization of fresh and fruity young white wines, the process of skin contact is becoming an interesting part of winemaking using neutral grapes. The lower concentration of grape-derived aromatic compounds from neutral varieties are manipulated by fermentative aromatics like esters, higher alcohols and volatile phenols. (Cabaroglu et al., 1997; Selli et al., 2003; Peinado et al., 2004; Cabrita et al., 2006; Sanchez Palomo et al., 2007; Lukic et al., 2008; Rodriguez Bencomo et al., 2008). In these wines made from neutral grapes, the aroma perceived is a result of the combination of various compounds and cannot be contributed to an individual aromatic component. This type of aroma is a major factor determining wine character and quality (Sanchez Palomo et al., 2006). With the exception of exogenous enzyme additions, the influence of skin contact time and temperature were the factors mostly controlled in the above mentioned articles. Only sporadic data about aromatic compounds concerning alternative techniques like freezing of whole grapes, heating or even carbonic maceration for white varieties are reported. (Benard et al., 1971; Marais, 1987; Bitteur et al., 1992; Sapis et al., 1995; Bitteur et al., 1996).

In this study, grapes from three traditionally and commercially important neutral varieties from Slovenia's Primorska region, i.e. Zelen, Ribolla Gialla and Malvasia Istriana, were subjected to some alternative skin contact techniques with the intention of producing fresh and fruity young wines. The four simple skin contact processes involved the addition of $6 \%$ and $12 \%$ grape berries respectively in must during alcoholic fermentation, the freezing of the pomace before pressing and the freezing of whole grapes before pressing. Free volatile aromatic compounds in wines were detected and quantified using GC-MS and GC-FID. Together with some standard chemical parameters, they where compared to the control wines produced without skin contact.

To evaluate the complex olfactory impact of different aromatic compounds, individual "odour activity values" (OAV) were calculated. The concentration/threshold ratio known as OAV allows the estimation of the contribution of a specific compound to the aroma of wine, yielding a complex aroma profile with all components quantified in the wine (Peinado et al., 2004). OAVs have been adopted to analyze the interactions between various aromatic compounds essential to the total aroma (Moyano et al., 2002; Peinado et al., 2004; Rocha et al., 2004; Selli et al., 2006; Chaves et al., 2007; Moyano et al., 2009). This method of aroma fraction study has the advantage of greatly reducing the number of variables to be interpreted, preserving their relative importance according to the OAVs of the compounds assembled, and it is valid for the comparison of wines of the same type (Moyano et al., 2002). Additionally, it was relevant to determine some olfactory important compounds in the Zelen and Ribolla Gialla wines, as only aromatic data for Malvasia Istriana var. are available (Kovacevic et al., 2005; Lukic et al., 2008). Finally, the sensorial evaluation (odour, overall impression) of wines and the statistical analysis (principal component analysis) were performed.

\section{MATERIALS AND METHODS Preparation of wine samples}

Healthy grapes of Zelen, Ribolla Gialla and Malvasia Istriana (50 kg of each) were manually harvested in 2009 at the ripeness stage corresponding to wines containing approximately $11 \%(\mathrm{v} / \mathrm{v})$ ethanol. Grapes of these individual varieties were each divided into five batches. Three batches were immediately destemmed, crushed and pressed up to 150 $\mathrm{kPa}$ using a small water press (Lancman VS-A 55, Slovenia). The juice was sulphited with $30 \mathrm{mg} / \mathrm{L}$ of sulphur dioxide, left to settle at $6^{\circ} \mathrm{C}$ for $12 \mathrm{~h}$, racked and divided into nine glass laboratory fermentor vessels containing $1.6 \mathrm{~L}$ juice each. In 3 vessels, $103 \mathrm{~g}$ of intact berries were added (B6 $=$ addition of $6 \%$ berries during alcoholic maceration), and in another 3 vessels $206 \mathrm{~g}$ of intact berries were added (B12 = addition of $12 \%$ berries during alcoholic maceration). The remaining 3 vessels were used as control wines $(\mathrm{K}=$ control without skin contact). The vessels were heated to $17^{\circ} \mathrm{C}$, inoculated with $0.2 \mathrm{~g} / \mathrm{L}$ of dried Saccharomyces cerevisiae (CM, Lallemand), supplemented with $0.2 \mathrm{~g} / \mathrm{L}$ complex yeast nutrient (Fermaid E, Lallemand) and fermented at this temperature. After alcoholic fermentations with residual sugars $<2.5 \mathrm{~g} / \mathrm{L}$ took place and when most of the lees had settled, the wines were racked, grape berries in B6 and B12 were eliminated, 50 $\mathrm{mg} / \mathrm{L}$ of sulphur dioxide was added and the wines were stored at $10^{\circ} \mathrm{C}$. The fourth batch $(\mathrm{Fp}=$ freezing of the pomace) was de-stemmed and crushed. The pomace was divided equally into three plastic vessels, frozen overnight at $-20^{\circ} \mathrm{C}$, defrosted at $20^{\circ} \mathrm{C}$ and pressed up to $150 \mathrm{kPa}$. The juice from the individual plastic vessels was sulphated with $30 \mathrm{mg} / \mathrm{L}$ of sulphur dioxide, left to settle at $6^{\circ} \mathrm{C}$ for 12 hours, racked and poured into 3 glass laboratory fermentor vessels again containing 1.6 L juice each. The vessels were heated to $17^{\circ} \mathrm{C}$, inoculated with $0.2 \mathrm{~g} / \mathrm{L}$ of dried Saccharomyces cerevisiae (CM, Lallemand), supplemented with $0.2 \mathrm{~g} / \mathrm{L}$ complex yeast nutrient (Fermaid E, Lallemand) and fermented at the same temperature. After alcoholic fermentations (residual sugars $<2.5 \mathrm{~g} / \mathrm{L}$ ) took place and when most of the lees had settled, the wines were racked, $50 \mathrm{mg} / \mathrm{L}$ of sulphur dioxide was added, and the wines were stored at $10^{\circ} \mathrm{C}$. Grapes from the fifth batch ( $\mathrm{Fg}=$ freezing of whole grapes) were divided into three plastic vessels, frozen overnight at $-20^{\circ} \mathrm{C}$, defrosted at $20^{\circ} \mathrm{C}$ and the whole grapes were pressed up to $150 \mathrm{kPa}$ without de-stemming or crushing. The remaining process to obtain wine was the same as described for Fp. Finally, five different processes in three repetitions were done for each variety.

These chemical analyses and sensorial evaluations were performed from December 2009 until January 2010.

\section{Standard chemical analyses}

As standard chemical analyses, ethanol (\%vol), dry extract $(\mathrm{g} / \mathrm{L})$, reducing sugars $(\mathrm{g} / \mathrm{L}), \mathrm{pH}$, total acidity $(\mathrm{g} / \mathrm{L}$ as tartaric acid), volatile acidity ( $\mathrm{g} / \mathrm{L}$ as acetic acid) and ash $(\mathrm{g} / \mathrm{L})$ were determined using standard methods (EEC, 1990).

Methanol (mg/L) was determined, as described later, together with the major volatile compounds using GC-FID. Total phenols $(\mathrm{mg} / \mathrm{L}$ as $(+)$ catechin) were determined using method proposed by Rigo et al. (2000). 


\section{Extraction of volatiles}

For the extraction of minor volatile compounds $(\mu \mathrm{g} / \mathrm{L})$ with exception of the terpenes, discontinuous liquid-liquid extraction (LLE) with dichloromethane (Sigma-Aldrich) was used. The wine $(100 \mathrm{~mL})$ was transferred into a 250 $\mathrm{mL}$ Erlenmeyer flask and cooled down to $0^{\circ} \mathrm{C}$ in an ice bath under nitrogen. To this, $23 \mu \mathrm{g}$ of 4-nonanol were added as internal standard, using a $0.05 \mathrm{~mL}$ Hamilton syringe from the corresponding ethanol solution. Dichloromethane $(40 \mathrm{~mL})$ was added and the mixture was stirred at $350 \mathrm{rpm}$ for 20 min (Moio et al., 1995). Then the mixture was centrifuged at $5^{\circ} \mathrm{C}(8500 \mathrm{~g}, 10 \mathrm{~min})$ and the organic phase was recovered. The aqueous phase was re-extracted twice in the using the some method. Finally, the organic phases were combined and dried over sodium sulphate. They were concentrated to a final volume of $1 \mathrm{~mL}$ with Vigreaux distillation column and nitrogen gas flow prior to GC-MS analysis (Moio et al., 1995; Schneider et al., 1998; Selli et al., 2006).

Standard volatiles with the highest available purity (minimum of 98\%) were obtained from Merck, Sigma Aldrich, Fluka and SAFC. Stock solutions of each of the standard volatiles in pure dichloromethane were prepared with concentrations ranging from 1.8 to $2.5 \mathrm{~g} / \mathrm{L}$. From the stock solutions, one mixed solution of all the minor volatiles was prepared and the final standards were prepared with proper dilutions from this flask. Internal standard 4-nonanol (0.12 g dissolved in $100 \mathrm{~mL}$ dichloromethane) was added using a $0.05 \mathrm{~mL}$ Hamilton syringe to $10 \mathrm{~mL}$ of dichloromethane standard solution and mixed.

For the extraction of terpenes $(\mu \mathrm{g} / \mathrm{L})$ headspace solid phase microextraction (HS-SPME) was introduced. All chemicals were of analytical grade. The terpene standards and HPLC grade methanol were obtained from Sigma Aldrich and water (Milli-Q). The wine sample was diluted with Milli-Q water (1:5) in a $20 \mathrm{~mL}$ SPME vial. $1.7 \mathrm{~g} \mathrm{NaCl}$ (100\% concentration) was added to adjust the ionic strength. After testing the Polydimethylsiloxane/Divinylbenzene (PDMS/DVB) fibre, an adsorption time of $60 \mathrm{~min}$ and an adsorption temperature of $40^{\circ} \mathrm{C}$ were chosen for the extraction before GC-MS.

For the standard solutions, each terpene standard (linalool, $\alpha$-terpineol, citronellol, nerol and geraniol) was weighed in a $100 \mathrm{~mL}$ volumetric flask and dissolved in methanol. Stock solution of standards with the concentration of $1 \mathrm{mg} / \mathrm{L}$ was obtained by further dilution with methanol. To obtain a standard solution with $10 \mathrm{mg} / \mathrm{L}$ concentrations, $50 \mu \mathrm{L}$ of standard stock solution was transferred in a $20 \mathrm{~mL}$ SPME vial and dissolved in $4.95 \mathrm{~mL}$ of Milli-Q water.

Major volatile compounds in wine $(\mathrm{mg} / \mathrm{L})$, namely ethyl acetate, 1-propanol, 1-butanol, 2-butanol, 2-methyl propanol (isobutyl alcohol), 2-methyl butanol, 3-methyl butanol (isoamyl alcohol), 2-phenylethanol and methanol were detected without previous extraction. In $5 \mathrm{~mL}$ of wine sample $0.05 \mathrm{~mL}$ of internal standard 4-methyl-2-pentanol (Sigma Aldrich; $2.78 \mathrm{~g}$ dissolved in $100 \mathrm{~mL}$ of absolute ethanol) was added and mixed. Standards for ethyl acetate (Carlo Erba), higher alcohols (Merck) and methanol (J.T. Baker) were prepared like stock solutions, mixed and diluted with $12 \%$ vol solution of absolute ethanol with Milli-Q water. Standards were mixed with internal standard in the same way as the wine samples.
Determination and quantification of volatile substances

Minor volatile compounds $(\mu \mathrm{g} / \mathrm{L})$ with the exception of terpenes were identified and quantified by gas chromatograph (GC) (Hewlett Packard 6890, Germany) coupled to a mass selective (MS) detector (Hewlett Packard 5793, USA). The chromatograph was equipped with the capillary column (Varian, CP-Wax 57CB, $50 \mathrm{~m}$ x $0.25 \mathrm{~mm}$; film thickness 0.20 $\mu \mathrm{m}$ ), precolumn (Agilent Technologies, FS deactivated, $2 \mathrm{~m}$ x $0.25 \mathrm{~mm}$ ) and liner (Agilent Technologies, part number 5062-3587). Helium 6.0 with constant flow $1.0 \mathrm{~mL} / \mathrm{min}$ was used as a carrier and the injection volume was $1.0 \mu \mathrm{L}$. The injector temperature was $200{ }^{\circ} \mathrm{C}$, injection type pulsed splitless, oven temperature gradient was $40^{\circ} \mathrm{C}$ for $12 \mathrm{~min}$, then from $40^{\circ} \mathrm{C}$ to $200^{\circ} \mathrm{C}$ at $5^{\circ} \mathrm{C} / \mathrm{min}$ and finally $20 \mathrm{~min}$ at $200^{\circ} \mathrm{C}$. The ion source temperature was $230^{\circ} \mathrm{C}$, the auxiliary temperature was $200^{\circ} \mathrm{C}$, and the quadrupole temperature was $150^{\circ} \mathrm{C}$. Calibration was done with the mixture of all the analysed compounds in dichloromethane. For identification, retention times and mass spectra (scanning was done in selective ion monitoring mode - SIM mode) were used. Linearity of the method was verified using the solutions of volatile compounds in dichloromethane (five repetitions for one concentration level, three to eight concentration levels for the calibration curve). Linearity and range were determined by linear regression using the $\mathrm{F}$ test. Linear model was fit and linear over a wide range (lowest 0.0058 $\mathrm{mg} / \mathrm{L}$ to $1.67 \mathrm{mg} / \mathrm{L}$ and highest $1.67 \mathrm{mg} / \mathrm{L}$ to $10.13 \mathrm{mg} / \mathrm{L}$ ). Limits of detection (LOD; $0.016 \mathrm{mg} / \mathrm{L}$ to $0.444 \mathrm{mg} / \mathrm{L}$ ) and limits of quantification (LOQ; $0.052 \mathrm{mg} / \mathrm{L}$ to $1.174 \mathrm{mg} / \mathrm{L}$ ) were calculated from the calibration curve $\left(\mathrm{R}^{2} ; 0.982\right.$ to 0.999). The concentration factor for wine samples was due to extraction 100 , so the realistic linearity range, LODs and LOQs were 100-times lower.

Terpenes $(\mu \mathrm{g} / \mathrm{L})$ were identified and quantified with GC (Agilent Technologies 7890A, China) coupled with MS detector (Agilent Technologies 5975C, USA). Autosampler MPS 2 (Gerstel, Germany) was used. The incubation time in the autosampler agitator was $5 \mathrm{~min}$, the agitator speed was $250 \mathrm{rpm}$ and the desorption time was $300 \mathrm{~s}$. The chromatograph was equipped with a capillary column (Agilent Technologies, INNOWax, $30 \mathrm{~m}$ x $0.25 \mathrm{~mm}$; film thickness $0.25 \mu \mathrm{m}$ ), precolumn (Agilent Technologies, FS deactivated $2 \mathrm{~m} \mathrm{x} 0.25 \mathrm{~mm}$ ) and liner (Agilent Technologies, part number 18740-80200). Helium 6.0 with constant flow $1.2 \mathrm{~mL} / \mathrm{min}$ was used as a carrier. The injector temperature was $250^{\circ} \mathrm{C}$, the injection type was splitless, the oven temperature gradient was $50^{\circ} \mathrm{C}$ for $5 \mathrm{~min}$, then from $50^{\circ} \mathrm{C}$ to $110^{\circ} \mathrm{C}$ at $5^{\circ} \mathrm{C} / \mathrm{min}$, from $110^{\circ} \mathrm{C}$ to $150^{\circ} \mathrm{C}$ at $2^{\circ} \mathrm{C} / \mathrm{min}$, from $150^{\circ} \mathrm{C}$ to $190^{\circ} \mathrm{C}$ at $1^{\circ} \mathrm{C} / \mathrm{min}$, from $190^{\circ} \mathrm{C}$ to $250^{\circ} \mathrm{C}$ at $20^{\circ} \mathrm{C} / \mathrm{min}$, and finally $15 \mathrm{~min}$ at $250^{\circ} \mathrm{C}$. The ion source temperature was $230^{\circ} \mathrm{C}$, the auxiliary temperature was $260^{\circ} \mathrm{C}$ and the quadrupole temperature was $150^{\circ} \mathrm{C}$. Calibration was done with the mixture of all the analysed terpenes. For identification, retention times and mass spectrums in SIM mode were used. Linearity was verified by using standard solutions with the concentrations of $0.1,0.5,1,5,10,25$, 50 , and $100 \mathrm{mg} / \mathrm{L}$ (four repetitions per concentration level). Linearity and range were determined by linear regression using the $\mathrm{F}$ test. The linear model was appropriate over a wide range (lowest $0.1 \mu \mathrm{g} / \mathrm{L}$ to $5 \mu \mathrm{g} / \mathrm{L}$, highest $25 \mu \mathrm{g} / \mathrm{L}$ to 
$50 \mu \mathrm{g} / \mathrm{L}$ ). Limits of detection (LODs; $0.4 \mu \mathrm{g} / \mathrm{L}$ to $3.0 \mu \mathrm{g} / \mathrm{L}$ ) and limits of quantification (LOQs; $1.5 \mu \mathrm{g} / \mathrm{L}$ to $10.1 \mu \mathrm{g} / \mathrm{L}$ ) were calculated from the calibration curve $\left(\mathrm{R}^{2} ; 0.983\right.$ to 0.996).

Major volatile compounds (mg/L) were identified and quantified by GC (Hewlett Packard 6890, Germany) coupled with a flame ionisation detector (FID). The chromatograph was equipped with a capillary column (Varian, CP-Wax 57CB, $50 \mathrm{~m}$ x $0.25 \mathrm{~mm}$; film thickness $0.20 \mu \mathrm{m}$ ) and liner (Agilent Technologies, part number 5183-4647). Nitrogen 5.0 with constant flow $1.0 \mathrm{~mL} / \mathrm{min}$ was used as a carrier and the injection volume was $1.0 \mu \mathrm{l}$. The injector temperature was $200^{\circ} \mathrm{C}$, the injection type split $(50: 1)$, the oven temperature gradient was $40^{\circ} \mathrm{C}$ for $10 \mathrm{~min}$, then from $40^{\circ} \mathrm{C}$ to $200^{\circ} \mathrm{C}$ at $5^{\circ} \mathrm{C} /$ min and finally $20 \mathrm{~min}$ at $200^{\circ} \mathrm{C}$. The detector temperature was $300^{\circ} \mathrm{C}$. Calibration was performed with the mixture of all the analysed compounds in $12 \%$ vol absolute ethanol. For identification, retention times were used. Linearity of the method was verified using the solutions of volatile compounds in $12 \%$ vol absolute ethanol (four repetitions for one concentration level, five to seven concentration levels for the calibration curve). Linearity and range were determined by linear regression using the $\mathrm{F}$ test. The linear model was appropriate over a wide range (lowest $0.5 \mathrm{mg} / \mathrm{L}$ to $7 \mathrm{mg} / \mathrm{L}$ and highest $77.2 \mathrm{mg} / \mathrm{L}$ to $542.4 \mathrm{mg} / \mathrm{L}$ ). Limits of detection (LODs; $0.07 \mathrm{mg} / \mathrm{L}$ to $0.41 \mathrm{mg} / \mathrm{L}$ ) and limits of quantification (LOQs; $0.24 \mathrm{mg} / \mathrm{L}$ to $1.38 \mathrm{mg} / \mathrm{L}$ ) were calculated from the calibration curve ( $\mathrm{R}^{2} ; 0.987$ to 0.999$)$.

\section{Sensory evaluation}

Wines were evaluated by a panel of assessors consisting of nine staff members of the Agricultural Institute of Slovenia wine evaluation group. They were selected according to their experience and knowledge of the typical character of the Zelen, Ribolla Gialla and Malvasia Istriana wines.

Wines were presented to them for each variety in the first (K, B6, B12) and the second group (K, Fp, Fg). In this way, three wines from different processes were compared at the same time with var. and vintage data known to the assessors. Only simple preferential hierarchical ranking (1-the most preferable, 2, 3-the least preferable) in one repetition was evaluated for two wine parameters, odour and overall impression, the later being the combination of odour, taste and harmony. Hierarchical ranking can be used when influences of different factors on wines are evaluated at the same time (Jackson, 2009). Finally, averages for odour and overall impression were calculated and the lowest number was chosen as the prefered wine.

\section{Statistical analysis}

A multivariate analysis of variance (MANOVA) was done of the standard chemical and aromatic compounds data using the Statgraphics ${ }^{\circledR}$ Centurion XVI statistical software package (StatPoint Technologies). Principal component analysis data were collected and edited using Excel XP and correlations between parameters were tested using the computer program SAS/STAT (SAS Software, 1990).

\section{RESULTS AND DISCUSSION \\ Wine composition}

The composition of the control and macerated wines is shown in Table 1. Wine composition of Zelen, Ribolla Gialla and Malvasia Istriana was clearly affected by freezing procedures Fp and Fg. Typical skin contact changes, like lower ethanol and total acidity content, but higher total dry extract, ash content and $\mathrm{pH}$ were detected as reported by other authors (Gerbi et al., 1991; Reynolds et al., 1993; Selli et al., 2006; Sanchez Palomo et al., 2007). With the exception of Zelen variety, reduction of total acidity due to tartaric acid lost with salification and freezing (Gerbi et al., 1991) was only minor in the Fp and Fg procedures. Total phenol content increased in all skin contact procedures, but not excessively. Methanol deriving from the demethylation of pectin was only slightly influenced by proposed maceration procedures and even lower concentrations were detected in Fp. It can be concluded that freezing processes Fp and Fg provoked more radical changes in general composition of wine than the addition of berries in the B6 and B12 procedures. Unfortunately, the cost of freezing in the Fp and Fg processes are higher than the simple berry additions.

\section{Aromatic compounds in wines}

Concentrations of individual aromatic compounds in the Zelen, Ribolla Gialla and Malvasia Istriana wines produced by K, B6, B12, Fp and Fg processes are shown in Tables 2, 3, 4. Maceration processes proved to have a positive effect on typical grape derived aromatic compounds like terpenes and benzyl alcohol in Zelen and Malvasia Istriana. It was found that in the Ribolla Gialla wines the terpene content was lower and minimally influenced by maceration. As far as the $\mathrm{C}_{6}$ volatiles deriving from grapes are concerned, $\mathrm{Fg}$ proved to be the most effective process for their extraction. Curiously, Fp gave even lower content than that of the control wines in Ribolla Gialla and Malvasia Istriana varieties. With the exception of Fp in Malvasia Istriana, lower content of total higher alcohols in macerated wines was determined. This could be the result of blockage of the Ehrlich mechanism, the main yeasts pathway for the formation of higher alcohols due to the increased levels of nitrogenous substances in macerated must (Rapp \& Versini, 1995; Sanchez Palomo et al., 2007). The total sum of higher alcohols never exceeded $400 \mathrm{mg} / \mathrm{L}$, i.e. the concentration which causes negative sensorial impact on wine aroma (Rapp \& Mandrey, 1986). In the Fp procedure the lowest content of total esters without ethyl lactate was detected for all three varieties. As for the total volatile phenols, there was no general conclusion regarding the maceration effects.

Some aromatic compounds like higher alcohols 2-butanol and 1-butanol were not detected in the concentrations above LOD. Ethyl cinnamate, a volatile compound, together with benzaldehyde, responsible for the cherry-raspberry smell of carbonic macerated red wines and an odour threshold of 30 $\mu \mathrm{g} / \mathrm{L}$, was not detected (Versini \& Tomasi, 1983). Volatile phenol 4-ethylguaiacol typical for red wines was also not detected. It has an undesirable smell of stables and sweaty saddles with an odour threshold of $46 \mu \mathrm{g} / \mathrm{L}$ (Chatonnet et al., 1992, 1993; Moreno et al., 2005). From grape deriving volatiles, $\mathrm{C}_{6}$ alcohol trans-2-hexene-1-ol, terpenes nerol and 
TABLE 1

General composition of the Zelen, Ribolla Gialla and Malvasia Istriana wines produced by different procedures (K-control without skin contact, B6 or B12-addition of $6 \%$ or $12 \%$ grape berries during alcoholic fermentation, Fp-freezing of the pomace, Fg-freezing of whole grapes).

\begin{tabular}{|c|c|c|c|c|c|}
\hline ZELEN & $\mathbf{K}$ & B6 & B12 & Fp & $\mathbf{F g}$ \\
\hline ethanol (\%vol) & $11.1 \pm 0.1^{\mathrm{b} *}$ & $10.9 \pm 0.1^{\mathrm{a}}$ & $11.0 \pm 0.1^{\mathrm{b}}$ & $10.9 \pm 0.1^{\mathrm{a}}$ & $11.0 \pm 0.1^{\mathrm{ab}}$ \\
\hline total dry extract $(\mathrm{g} / \mathrm{L})$ & $19.6 \pm 0.2^{\mathrm{a}}$ & $19.6 \pm 0.3^{\mathrm{a}}$ & $19.5 \pm 0.4^{\mathrm{a}}$ & $20.2 \pm 0.1^{\mathrm{b}}$ & $20.5 \pm 0.2^{b}$ \\
\hline reducing sugar $(\mathrm{g} / \mathrm{L})$ & $1.4 \pm 0.1^{\mathrm{a}}$ & $1.9 \pm 0.1^{\mathrm{b}}$ & $2.1 \pm 0.1^{\mathrm{c}}$ & $1.4 \pm 0.1^{\mathrm{a}}$ & $2.2 \pm 0.1^{\mathrm{c}}$ \\
\hline pH (-) & $3.02 \pm 0.01^{\mathrm{a}}$ & $3.04 \pm 0.02^{\mathrm{a}}$ & $3.08 \pm 0.01^{\mathrm{b}}$ & $3.35 \pm 0.03^{\mathrm{d}}$ & $3.27 \pm 0.01^{\mathrm{c}}$ \\
\hline total acidity $(\mathrm{g} / \mathrm{L})$ & $7.3 \pm 0.1^{\mathrm{e}}$ & $7.2 \pm 0.0^{\mathrm{d}}$ & $6.9 \pm 0.1^{\mathrm{c}}$ & $6.1 \pm 0.1^{\mathrm{b}}$ & $5.9 \pm 0.1^{\mathrm{a}}$ \\
\hline volatile acidity (g/L) & $0.17 \pm 0.01^{\mathrm{ab}}$ & $0.19 \pm 0.01^{\mathrm{bc}}$ & $0.16 \pm 0.01^{\mathrm{a}}$ & $0.20 \pm 0.01^{\mathrm{c}}$ & $0.17 \pm 0.02^{\mathrm{ab}}$ \\
\hline $\operatorname{ash}(g / L)$ & $1.61 \pm 0.03^{\mathrm{a}}$ & $1.67 \pm 0.04^{\mathrm{a}}$ & $1.65 \pm 0.05^{\mathrm{a}}$ & $2.21 \pm 0.03^{\mathrm{c}}$ & $2.10 \pm 0.02^{\mathrm{b}}$ \\
\hline methanol (mg/L) & $27.1 \pm 0.7^{\mathrm{b}}$ & $31.1 \pm 1.1^{\mathrm{c}}$ & $34.0 \pm 1.0^{\mathrm{d}}$ & $24.6 \pm 0.2^{\mathrm{a}}$ & $34.0 \pm 1.5^{\mathrm{d}}$ \\
\hline total phenols $(\mathrm{mg} / \mathrm{L})$ & $134 \pm 7^{\mathrm{a}}$ & $145 \pm 2^{\mathrm{ab}}$ & $157 \pm 2^{\mathrm{b}}$ & $160 \pm 3^{b}$ & $148 \pm 11^{\mathrm{ab}}$ \\
\hline RIBOLLA G. & $\mathbf{K}$ & B6 & B12 & Fp & Fg \\
\hline ethanol (\%vol) & $11.2 \pm 0.1^{\mathrm{b}}$ & $11.2 \pm 0.1^{\mathrm{b}}$ & $11.1 \pm 0.1^{\mathrm{b}}$ & $10.7 \pm 0.1^{\mathrm{a}}$ & $10.7 \pm 0.2^{\mathrm{a}}$ \\
\hline total dry extract $(\mathrm{g} / \mathrm{L})$ & $17.5 \pm 0.3^{\mathrm{a}}$ & $17.7 \pm 0.1^{\mathrm{a}}$ & $18.2 \pm 0.3^{\mathrm{b}}$ & $18.8 \pm 0.2^{\mathrm{c}}$ & $18.3 \pm 0.2^{c}$ \\
\hline reducing sugar $(\mathrm{g} / \mathrm{L})$ & $1.4 \pm 0.1^{\mathrm{ab}}$ & $1.6 \pm 0.1^{\mathrm{bc}}$ & $1.7 \pm 0.3^{\mathrm{c}}$ & $1.4 \pm 0.1^{\mathrm{ab}}$ & $1.2 \pm 0.1^{\mathrm{a}}$ \\
\hline $\mathrm{pH}(-)$ & $3.29 \pm 0.02^{\mathrm{a}}$ & $3.30 \pm 0.03^{\mathrm{a}}$ & $3.32 \pm 0.03^{\mathrm{a}}$ & $3.40 \pm 0.02^{b}$ & $3.42 \pm 0.04^{\mathrm{b}}$ \\
\hline total acidity $(\mathrm{g} / \mathrm{L})$ & $5.5 \pm 0.1^{\mathrm{b}}$ & $5.5 \pm 0.1^{\mathrm{b}}$ & $5.5 \pm 0.1^{\mathrm{b}}$ & $5.4 \pm 0.1^{\mathrm{b}}$ & $4.9 \pm 0.1^{\mathrm{a}}$ \\
\hline volatile acidity (g/L) & $0.12 \pm 0.01^{\mathrm{a}}$ & $0.11 \pm 0.02^{\mathrm{a}}$ & $0.11 \pm 0.01^{\mathrm{a}}$ & $0.10 \pm 0.01^{\mathrm{a}}$ & $0.11 \pm 0.02^{\mathrm{a}}$ \\
\hline $\operatorname{ash}(g / L)$ & $1.45 \pm 0.04^{\mathrm{a}}$ & $1.43 \pm 0.01^{\mathrm{a}}$ & $1.46 \pm 0.04^{\mathrm{a}}$ & $1.81 \pm 0.05^{\mathrm{c}}$ & $1.75 \pm 0.03^{b}$ \\
\hline methanol (mg/L) & $34.0 \pm 0.8^{b}$ & $36.4 \pm 0.5^{b}$ & $39.7 \pm 3.0^{c}$ & $15.6 \pm 0.8^{\mathrm{a}}$ & $35.4 \pm 1.5^{\mathrm{b}}$ \\
\hline total phenols $(\mathrm{mg} / \mathrm{L})$ & $67 \pm 3^{\mathrm{a}}$ & $80 \pm 4^{b}$ & $90 \pm 8^{\mathrm{cd}}$ & $94 \pm 3^{d}$ & $83 \pm 1^{\mathrm{bc}}$ \\
\hline MALVASIA I. & $\mathbf{K}$ & B6 & B12 & Fp & Fg \\
\hline ethanol $(\% \mathrm{vol})$ & $10.9 \pm 0.1^{\mathrm{b}}$ & $11.0 \pm 0.2^{b}$ & $11.0 \pm 0.2^{\mathrm{b}}$ & $10.6 \pm 0.1^{\mathrm{a}}$ & $10.6 \pm 0.1^{\mathrm{a}}$ \\
\hline total dry extract $(\mathrm{g} / \mathrm{L})$ & $18.5 \pm 0.2^{\mathrm{a}}$ & $18.8 \pm 0.3^{\mathrm{ab}}$ & $18.8 \pm 0.1^{\mathrm{ab}}$ & $19.8 \pm 0.3^{c}$ & $19.5 \pm 0.9^{b c}$ \\
\hline reducing sugar $(\mathrm{g} / \mathrm{L})$ & $1.4 \pm 0.2^{\mathrm{ab}}$ & $1.6 \pm 0.1^{\mathrm{bc}}$ & $1.8 \pm 0.1^{\mathrm{c}}$ & $1.2 \pm 0.1^{\mathrm{a}}$ & $1.6 \pm 0.4^{\mathrm{bc}}$ \\
\hline pH (-) & $3.23 \pm 0.02^{\mathrm{a}}$ & $3.27 \pm 0.01^{\mathrm{b}}$ & $3.29 \pm 0.01^{\mathrm{b}}$ & $3.42 \pm 0.02^{\mathrm{d}}$ & $3.39 \pm 0.01^{\mathrm{c}}$ \\
\hline total acidity $(\mathrm{g} / \mathrm{L})$ & $5.8 \pm 0.0^{\mathrm{ab}}$ & $6.0 \pm 0.1^{b}$ & $5.7 \pm 0.1^{\mathrm{ab}}$ & $5.9 \pm 0.1^{b}$ & $5.6 \pm 0.3^{\mathrm{a}}$ \\
\hline volatile acidity $(\mathrm{g} / \mathrm{L})$ & $0.11 \pm 0.01^{\mathrm{a}}$ & $0.10 \pm 0.01^{\mathrm{a}}$ & $0.12 \pm 0.03^{\mathrm{a}}$ & $0.12 \pm 0.02^{\mathrm{a}}$ & $0.13 \pm 0.02^{\mathrm{a}}$ \\
\hline $\operatorname{ash}(g / L)$ & $1.58 \pm 0.02^{\mathrm{a}}$ & $1.63 \pm 0.03^{\mathrm{b}}$ & $1.63 \pm 0.02^{\mathrm{b}}$ & $2.09 \pm 0.02^{\mathrm{d}}$ & $2.01 \pm 0.03^{\mathrm{c}}$ \\
\hline methanol (mg/L) & $25.6 \pm 0.7^{\mathrm{b}}$ & $28.5 \pm 1.3^{\mathrm{bc}}$ & $29.5 \pm 1.2^{\mathrm{c}}$ & $9.5 \pm 3.0^{\mathrm{a}}$ & $27.7 \pm 1.4^{\mathrm{bc}}$ \\
\hline total phenols $(\mathrm{mg} / \mathrm{L})$ & $64 \pm 1^{\mathrm{a}}$ & $72 \pm 2^{\mathrm{b}}$ & $82 \pm 2^{\mathrm{d}}$ & $76 \pm 3^{\mathrm{bc}}$ & $80 \pm 5^{\mathrm{cd}}$ \\
\hline
\end{tabular}

*All data present mean value \pm standard deviation $(\mathrm{n}=3)$.

Significant differences between procedures are indicated $a, b, c, d$ at $p \leq 0.05$.

geraniol and $\mathrm{C}_{13}$ norisoprenoid $\beta$-ionone were not detected in the Zelen, Ribolla Gialla or Malvasia Istriana wines.

Several aromatic compounds were detected in concentrations below their odour threshold. They are: 1-propanol with an alcoholic, ripe fruit smell and an odour threshold of $314 \mathrm{mg} / \mathrm{L}$ (Moyano et al., 2002); hexyl acetate with an apple-pear smell and an odour threshold of 670 $\mu \mathrm{g} / \mathrm{L}$ (Peinado et al., 2004); ethyl lactate with a buttery-fatty smell and a high odour threshold of $100 \mathrm{mg} / \mathrm{L}$ (Moyano et al., 2009); ethyl decanoate with a fruity-grape smell and an odour threshold of $510 \mu \mathrm{g} / \mathrm{L}$ (Chaves et al., 2007, Moyano et al., 2009); diethyl succinate, ethyl dodecanoate and ethyl hexadecanoate with a fruity-floral-lardy smell and odour thresholds of $100 \mathrm{mg} / \mathrm{L}, 1000 \mu \mathrm{g} / \mathrm{L}$ and $500 \mu \mathrm{g} / \mathrm{L}$, respectively (Moyano et al., 2002, 2009); cis-3-hexen-1-ol with a green-herbaceous-fatty smell and an odour threshold of $400 \mu \mathrm{g} / \mathrm{L}$ (Guth, 1997); 4-vinylphenol with undesirable medicinal-chemical flavours and an odour threshold of $725 \mu \mathrm{g} / \mathrm{L}$ (Chatonnet et al., 1992, 1993); $\alpha$-terpineol with a lilac-floral smell and an odour threshold of $250 \mu \mathrm{g} / \mathrm{L}$ (Guth, 1997); benzyl alcohol with a high odour threshold of 900 $\mathrm{mg} / \mathrm{L}$ (Moreno et al., 2005); benzaldehyde with an almond smell and an odour threshold of $2 \mathrm{mg} / \mathrm{L}$ (Peinado et al., 2004) and $\gamma$-butyrolactone with a caramel-buttery smell and an odour threshold of $20 \mu \mathrm{g} / \mathrm{L}$ (Peinado et al., 2004, Moyano et al., 2002). Whereas for 2-methyl butanol, there is no data available about its odour threshold.

Aromatic compounds detected in the concentrations above their odour threshold in at least one of the varieties are listed in Table 5, together with their odour thresholds, odour description and assignation of compounds to different odorant series. 
TABLE 2

Concentrations of individual aromatic compounds in the Zelen wines produced by different procedures (K-control without skin contact, B6 or B12-addition of $6 \%$ or $12 \%$ grape berries during alcoholic fermentation, Fp-freezing of the pomace, Fg-freezing of whole grapes).

\begin{tabular}{|c|c|c|c|c|c|}
\hline Aromatic compounds & $\mathbf{K}$ & B6 & B12 & $\mathbf{F p}$ & Fg \\
\hline ethyl acetate $(\mathrm{mg} / \mathrm{L})$ & $28.8 \pm 0.5^{\mathrm{c} *}$ & $29.7 \pm 0.3^{\mathrm{d}}$ & $30.7 \pm 0.5^{\mathrm{e}}$ & $21.6 \pm 0.3^{\mathrm{a}}$ & $23.8 \pm 0.5^{b}$ \\
\hline 2-butanol (mg/L) & n.d. & n.d. & n.d. & n.d. & n.d. \\
\hline 1-propanol (mg/L) & $19.8 \pm 0.1^{\mathrm{c}}$ & $19.4 \pm 0.7^{\mathrm{bc}}$ & $18.2 \pm 0.2^{\mathrm{b}}$ & $15.7 \pm 0.5^{\mathrm{a}}$ & $24.5 \pm 1.6^{\mathrm{d}}$ \\
\hline 2-methyl propanol (mg/L) & $39.4 \pm 2.3^{\mathrm{c}}$ & $40.0 \pm 1.0^{\mathrm{c}}$ & $33.9 \pm 2.8^{\mathrm{b}}$ & $39.6 \pm 1.5^{\mathrm{c}}$ & $27.1 \pm 0.8^{\mathrm{a}}$ \\
\hline 1-butanol (mg/L) & n.d. & n.d. & n.d. & n.d. & n.d. \\
\hline 2-methyl butanol (mg/L) & $48.5 \pm 0.3^{\mathrm{c}}$ & $48.3 \pm 0.4^{\mathrm{c}}$ & $45.7 \pm 0.1^{\mathrm{b}}$ & $48.9 \pm 1.4^{\mathrm{b}}$ & $43.4 \pm 0.8^{\mathrm{a}}$ \\
\hline 3-methyl butanol (mg/L) & $193.6 \pm 1.7^{\mathrm{c}}$ & $192.2 \pm 1.5^{\mathrm{bc}}$ & $189.1 \pm 0.7^{\mathrm{b}}$ & $183.0 \pm 3.3^{\mathrm{a}}$ & $181.9 \pm 3.3^{a}$ \\
\hline total higher alcohols $(\mathrm{mg} / \mathrm{L})$ & 343.3 & 339.1 & 329.9 & 328.5 & 319.4 \\
\hline ethyl butanoate $(\mu \mathrm{g} / \mathrm{L})$ & $187 \pm 5^{\mathrm{d}}$ & $176 \pm 6^{c}$ & $202 \pm 9^{e}$ & $126 \pm 6^{a}$ & $139 \pm 3^{\mathrm{b}}$ \\
\hline ethyl hexanoate $(\mu \mathrm{g} / \mathrm{L})$ & $415 \pm 8^{\mathrm{b}}$ & $423 \pm 43^{b}$ & $496 \pm 17^{c}$ & $294 \pm 17^{\mathrm{a}}$ & $432 \pm 6^{b}$ \\
\hline hexyl acetate $(\mu \mathrm{g} / \mathrm{L})$ & $69 \pm 2^{e}$ & $36 \pm 2^{c}$ & $24 \pm 1^{\mathrm{a}}$ & $28 \pm 1^{b}$ & $47 \pm 3^{d}$ \\
\hline ethyl lactate $(\mu \mathrm{g} / \mathrm{L})$ & $2370 \pm 29^{d}$ & $2220 \pm 42^{c}$ & $2128 \pm 45^{\mathrm{b}}$ & $1217 \pm 14^{\mathrm{a}}$ & $1257 \pm 3^{a}$ \\
\hline ethyl octanoate $(\mu \mathrm{g} / \mathrm{L})$ & $509 \pm 32^{c}$ & $458 \pm 13^{b}$ & $533 \pm 12^{c}$ & $415 \pm 28^{\mathrm{a}}$ & $440 \pm 16^{\mathrm{ab}}$ \\
\hline ethyl decanoate $(\mu \mathrm{g} / \mathrm{L})$ & $235 \pm 5^{\mathrm{c}}$ & $196 \pm 9^{\mathrm{ab}}$ & $200 \pm 4^{\mathrm{b}}$ & $199 \pm 13^{b}$ & $179 \pm 15^{\mathrm{a}}$ \\
\hline diethyl succinate $(\mu \mathrm{g} / \mathrm{L})$ & $100 \pm 7^{\mathrm{c}}$ & $95 \pm 11^{\mathrm{bc}}$ & $98 \pm 5^{\mathrm{bc}}$ & $74 \pm 2^{\mathrm{a}}$ & $87 \pm 4^{b}$ \\
\hline ethyl dodecanoate $(\mu \mathrm{g} / \mathrm{L})$ & $20 \pm 1^{\mathrm{bc}}$ & $18 \pm 1^{\mathrm{a}}$ & $19 \pm 1^{\mathrm{ab}}$ & $20 \pm 1^{\mathrm{bc}}$ & $21 \pm 2^{\mathrm{c}}$ \\
\hline ethyl cinammate $(\mu \mathrm{g} / \mathrm{L})$ & n.d. & n.d. & n.d. & n.d. & n.d. \\
\hline ethyl hexadecanoate $(\mu \mathrm{g} / \mathrm{L})$ & $10 \pm 2^{\mathrm{a}}$ & $12 \pm 4^{\mathrm{a}}$ & $8 \pm 1^{\mathrm{a}}$ & $9 \pm 3^{\mathrm{a}}$ & $11 \pm 1^{\mathrm{a}}$ \\
\hline isoamyl acetate $(\mu \mathrm{g} / \mathrm{L})$ & $1315 \pm 16^{\mathrm{c}}$ & $1151 \pm 61^{b}$ & $1209 \pm 82^{b}$ & $779 \pm 4^{\mathrm{a}}$ & $1138 \pm 29^{b}$ \\
\hline 2-phenylethyl acetate $(\mu \mathrm{g} / \mathrm{L})$ & $233 \pm 2^{d}$ & $156 \pm 7^{\mathrm{b}}$ & $134 \pm 7^{\mathrm{a}}$ & $131 \pm 4^{\mathrm{a}}$ & $198 \pm 3^{\mathrm{c}}$ \\
\hline total esters $(\mu g / L)$ & 5463 & 4941 & 5051 & 3292 & 3949 \\
\hline 1-hexanol $(\mu \mathrm{g} / \mathrm{L})$ & $665 \pm 10^{b}$ & $637 \pm 4^{\mathrm{a}}$ & $633 \pm 15^{\mathrm{a}}$ & $743 \pm 20^{c}$ & $1929 \pm 21^{\mathrm{d}}$ \\
\hline cis-3-hexen-1-ol $(\mu \mathrm{g} / \mathrm{L})$ & $6 \pm 2^{\mathrm{a}}$ & $5 \pm 2^{\mathrm{a}}$ & $6 \pm 3^{\mathrm{a}}$ & $8 \pm 3^{\mathrm{a}}$ & $18 \pm 0^{\mathrm{b}}$ \\
\hline trans-2-hexen-1-ol $(\mu \mathrm{g} / \mathrm{L})$ & n.d. & n.d. & n.d. & n.d. & n.d. \\
\hline total $C_{6}$ volatiles $(\mu g / L)$ & 671 & 642 & 639 & 751 & 1947 \\
\hline 4-vinylphenol $(\mu \mathrm{g} / \mathrm{L})$ & $83 \pm 5^{\mathrm{ab}}$ & $86 \pm 3^{\mathrm{ab}}$ & $99 \pm 5^{\mathrm{bc}}$ & $109 \pm 24^{c}$ & $66 \pm 3^{\mathrm{a}}$ \\
\hline 4-ethylguaiacol $(\mu \mathrm{g} / \mathrm{L})$ & n.d. & n.d. & n.d. & n.d. & n.d. \\
\hline 4-vinylguaiacol $(\mu \mathrm{g} / \mathrm{L})$ & $870 \pm 140^{\mathrm{a}}$ & $1049 \pm 40^{\mathrm{a}}$ & $1156 \pm 74^{\mathrm{a}}$ & $891 \pm 335^{\mathrm{a}}$ & $1066 \pm 52^{\mathrm{a}}$ \\
\hline total volatile phenols $(\mu \mathrm{g} / \mathrm{L})$ & 953 & 1135 & 1255 & 1001 & 1132 \\
\hline linalool $(\mu \mathrm{g} / \mathrm{L})$ & $33 \pm 3^{\mathrm{a}}$ & $44 \pm 2^{b}$ & $48 \pm 2^{\mathrm{b}}$ & $68 \pm 4^{\mathrm{c}}$ & $69 \pm 6^{c}$ \\
\hline$\alpha$-terpineol $(\mu \mathrm{g} / \mathrm{L})$ & $65 \pm 3^{\mathrm{a}}$ & $72 \pm 4^{\mathrm{a}}$ & $100 \pm 7^{\mathrm{b}}$ & $128 \pm 6^{c}$ & $169 \pm 6^{\mathrm{d}}$ \\
\hline citronellol $(\mu \mathrm{g} / \mathrm{L})$ & $23 \pm 2^{\mathrm{a}}$ & $27 \pm 0,6^{\mathrm{b}}$ & $27 \pm 2^{b}$ & $31 \pm 1^{\mathrm{c}}$ & $31 \pm 1^{\mathrm{c}}$ \\
\hline nerol $(\mu \mathrm{g} / \mathrm{L})$ & n.d. & n.d. & n.d. & n.d. & n.d. \\
\hline geraniol $(\mu \mathrm{g} / \mathrm{L})$ & n.d. & n.d. & n.d. & n.d. & n.d. \\
\hline total terpenes $(\mu g / L)$ & 121 & 143 & 175 & 227 & 269 \\
\hline benzyl alcohol $(\mu \mathrm{g} / \mathrm{L})$ & $12 \pm 0^{\mathrm{a}}$ & $23 \pm 2^{b}$ & $34 \pm 2^{\mathrm{c}}$ & $52 \pm 3^{\mathrm{d}}$ & $58 \pm 0^{\mathrm{e}}$ \\
\hline benzaldehyde $(\mu \mathrm{g} / \mathrm{L})$ & $1 \pm 0^{\mathrm{ab}}$ & $2 \pm 0^{\mathrm{b}}$ & $1 \pm 0^{\mathrm{a}}$ & $2 \pm 0^{\mathrm{b}}$ & $1 \pm 0^{\mathrm{ab}}$ \\
\hline$\beta$-ionone $(\mu \mathrm{g} / \mathrm{L})$ & n.d. & n.d. & n.d. & n.d. & n.d. \\
\hline$\gamma$-butyrolactone $(\mu \mathrm{g} / \mathrm{L})$ & $1520 \pm 18^{b}$ & $1656 \pm 36^{c}$ & $2009 \pm 25^{\mathrm{e}}$ & $1856 \pm 18^{\mathrm{d}}$ & $1162 \pm 39^{a}$ \\
\hline
\end{tabular}

n.d. $=$ not detected.

*All data present mean value \pm standard deviation $(n=3)$.

Significant differences between procedures are indicated $\mathrm{a}, \mathrm{b}, \mathrm{c}, \mathrm{d}$, e at $\mathrm{p} \leq 0.05$. 
TABLE 3

Concentrations of individual aromatic compounds in the Ribolla Gialla wines produced by different procedures (K-control without skin contact, B6 or B12-addition of $6 \%$ or $12 \%$ grape berries during alcoholic fermentation, Fp-freezing of the pomace, Fg-freezing of whole grapes).

\begin{tabular}{|c|c|c|c|c|c|}
\hline Aromatic compounds & $\mathbf{K}$ & B6 & B12 & Fp & Fg \\
\hline ethyl acetate $(\mathrm{mg} / \mathrm{L})$ & $39.4 \pm 0.6^{\mathrm{b} *}$ & $44.2 \pm 1.1^{\mathrm{c}}$ & $47.5 \pm 0.7^{\mathrm{d}}$ & $32.0 \pm 1.1^{\mathrm{a}}$ & $54.0 \pm 1.4^{\mathrm{e}}$ \\
\hline 2-butanol (mg/L) & n.d. & n.d. & n.d. & n.d. & n.d. \\
\hline 1-propanol (mg/L) & $24.8 \pm 0.7^{\mathrm{a}}$ & $24.5 \pm 0.4^{\mathrm{a}}$ & $25.4 \pm 1.1^{\mathrm{a}}$ & $27.5 \pm 0.4^{\mathrm{b}}$ & $26.9 \pm 0.5^{b}$ \\
\hline 2-methyl propanol (mg/L) & $34.1 \pm 2.3^{\mathrm{c}}$ & $31.2 \pm 0.2^{\mathrm{b}}$ & $35.2 \pm 1.4^{\mathrm{b}}$ & $35.4 \pm 1.2^{\mathrm{c}}$ & $27.3 \pm 1.1^{\mathrm{a}}$ \\
\hline 1-butanol (mg/L) & n.d. & n.d. & n.d. & n.d. & n.d. \\
\hline 2-methyl butanol (mg/L) & $45.4 \pm 3.0^{\mathrm{cd}}$ & $43.4 \pm 0.9^{\mathrm{bc}}$ & $42.0 \pm 0.9^{\mathrm{b}}$ & $48.3 \pm 1.2^{\mathrm{d}}$ & $36.7 \pm 1.1^{\mathrm{a}}$ \\
\hline 3-methyl butanol (mg/L) & $175.9 \pm 10.0^{c}$ & $164.3 \pm 2.4^{b}$ & $157.2 \pm 5.0^{\mathrm{b}}$ & $161.8 \pm 5.3^{\mathrm{b}}$ & $127.1 \pm 6.0^{\mathrm{a}}$ \\
\hline 2-phenylethanol (mg/L) & $32.3 \pm 2.6^{\mathrm{c}}$ & $28.3 \pm 0.7^{\mathrm{b}}$ & $28.8 \pm 1.0^{\mathrm{b}}$ & $29.3 \pm 0.7^{\mathrm{b}}$ & $22.4 \pm 0.4^{\mathrm{a}}$ \\
\hline total higher alcohols $(\mathrm{mg} / \mathrm{L})$ & 312.5 & 291.7 & 288.6 & 302.3 & 240.4 \\
\hline ethyl butanoate $(\mu \mathrm{g} / \mathrm{L})$ & $318 \pm 37^{\mathrm{b}}$ & $361 \pm 12^{c}$ & $374 \pm 14^{\mathrm{c}}$ & $265 \pm 12^{\mathrm{a}}$ & $346 \pm 18^{\mathrm{bc}}$ \\
\hline ethyl hexanoate $(\mu \mathrm{g} / \mathrm{L})$ & $721 \pm 101^{b}$ & $817 \pm 36^{\mathrm{b}}$ & $966 \pm 57^{\mathrm{c}}$ & $520 \pm 10^{\mathrm{a}}$ & $739 \pm 54^{\mathrm{b}}$ \\
\hline hexyl acetate $(\mu \mathrm{g} / \mathrm{L})$ & $210 \pm 15^{\mathrm{d}}$ & $129 \pm 8^{\mathrm{c}}$ & $94 \pm 3^{b}$ & $69 \pm 3^{a}$ & $544 \pm 24^{\mathrm{e}}$ \\
\hline ethyl lactate $(\mu \mathrm{g} / \mathrm{L})$ & $1184 \pm 26^{\mathrm{d}}$ & $1137 \pm 115^{d}$ & $1012 \pm 73^{c}$ & $864 \pm 33^{b}$ & $722 \pm 21^{\mathrm{a}}$ \\
\hline ethyl octanoate $(\mu \mathrm{g} / \mathrm{L})$ & $910 \pm 109^{\mathrm{bc}}$ & $886 \pm 46^{b}$ & $935 \pm 9^{b c}$ & $756 \pm 7^{\mathrm{a}}$ & $1003 \pm 59^{c}$ \\
\hline ethyl decanoate $(\mu \mathrm{g} / \mathrm{L})$ & $319 \pm 60^{\mathrm{a}}$ & $311 \pm 15^{\mathrm{a}}$ & $306 \pm 9^{a}$ & $325 \pm 7^{\mathrm{ab}}$ & $379 \pm 24^{\mathrm{b}}$ \\
\hline diethyl succinate $(\mu \mathrm{g} / \mathrm{L})$ & $45 \pm 3^{b}$ & $49 \pm 9^{b}$ & $47 \pm 2^{b}$ & $57 \pm 4^{c}$ & $33 \pm 2^{\mathrm{a}}$ \\
\hline ethyl dodecanoate $(\mu \mathrm{g} / \mathrm{L})$ & $15 \pm 5^{\mathrm{a}}$ & $17 \pm 1^{\mathrm{a}}$ & $20 \pm 1^{\mathrm{ab}}$ & $26 \pm 1^{\mathrm{c}}$ & $24 \pm 4^{\mathrm{bc}}$ \\
\hline ethyl cinammate $(\mu \mathrm{g} / \mathrm{L})$ & n.d. & n.d. & n.d. & n.d. & n.d. \\
\hline ethyl hexadecanoate $(\mu \mathrm{g} / \mathrm{L})$ & $12 \pm 1^{\mathrm{a}}$ & $12 \pm 2^{\mathrm{a}}$ & $14 \pm 4^{\mathrm{ab}}$ & $17 \pm 1^{\mathrm{b}}$ & $12 \pm 1^{\mathrm{a}}$ \\
\hline isoamyl acetate $(\mu \mathrm{g} / \mathrm{L})$ & $4371 \pm 364^{\mathrm{b}}$ & $4494 \pm 260^{b}$ & $4322 \pm 36^{\mathrm{b}}$ & $2771 \pm 75^{\mathrm{a}}$ & $5264 \pm 291^{\mathrm{c}}$ \\
\hline 2-phenylethyl acetate $(\mu \mathrm{g} / \mathrm{L})$ & $534 \pm 37^{\mathrm{e}}$ & $431 \pm 30^{\mathrm{b}}$ & $342 \pm 14^{\mathrm{a}}$ & $317 \pm 4^{\mathrm{a}}$ & $575 \pm 49^{c}$ \\
\hline total esters $(\mu g / L)$ & 8647 & 8650 & 8437 & 5987 & 9641 \\
\hline 1-hexanol $(\mu \mathrm{g} / \mathrm{L})$ & $616 \pm 8^{b}$ & $627 \pm 7^{b}$ & $614 \pm 21^{\mathrm{b}}$ & $303 \pm 10^{\mathrm{a}}$ & $911 \pm 28^{c}$ \\
\hline$c i s-3$-hexen-1-ol $(\mu \mathrm{g} / \mathrm{L})$ & n.d. & n.d. & n.d. & n.d. & $6 \pm 1$ \\
\hline trans-2-hexen-1-ol ( $\mu \mathrm{g} / \mathrm{L})$ & n.d. & n.d. & n.d. & n.d. & n.d. \\
\hline total $C_{6}$ volatiles $(\mu \mathrm{g} / \mathrm{L})$ & 616 & 627 & 614 & 303 & 917 \\
\hline 4-vinylphenol ( $\mu \mathrm{g} / \mathrm{L})$ & $466 \pm 2^{c}$ & $436 \pm 18^{b}$ & $438 \pm 2^{b}$ & $577 \pm 11^{\mathrm{d}}$ & $317 \pm 10^{\mathrm{a}}$ \\
\hline 4-ethylguaiacol $(\mu \mathrm{g} / \mathrm{L})$ & n.d. & n.d. & n.d. & n.d. & n.d. \\
\hline 4-vinylguaiacol $(\mu \mathrm{g} / \mathrm{L})$ & $534 \pm 6^{\mathrm{ab}}$ & $509 \pm 20^{\mathrm{a}}$ & $510 \pm 11^{\mathrm{a}}$ & $640 \pm 6^{\mathrm{c}}$ & $559 \pm 25^{\mathrm{b}}$ \\
\hline total volatile phenols $(\mu g / L)$ & 1000 & 945 & 948 & 1217 & 876 \\
\hline linalool $(\mu \mathrm{g} / \mathrm{L})$ & $7 \pm 2^{\mathrm{a}}$ & $8 \pm 1^{\mathrm{a}}$ & $8 \pm 1^{\mathrm{a}}$ & $7 \pm 1^{\mathrm{a}}$ & $7 \pm 1^{\mathrm{a}}$ \\
\hline$\alpha$-terpineol $(\mu \mathrm{g} / \mathrm{L})$ & n.d. & n.d. & n.d. & n.d. & n.d. \\
\hline citronellol $(\mu \mathrm{g} / \mathrm{L})$ & $19 \pm 4^{\mathrm{a}}$ & $19 \pm 3^{\mathrm{ab}}$ & $22 \pm 5^{\mathrm{ab}}$ & $27 \pm 6^{\mathrm{b}}$ & $18 \pm 4^{\mathrm{a}}$ \\
\hline $\operatorname{nerol}(\mu \mathrm{g} / \mathrm{L})$ & n.d. & n.d. & n.d. & n.d. & n.d. \\
\hline geraniol $(\mu \mathrm{g} / \mathrm{L})$ & n.d. & n.d. & n.d. & n.d. & n.d. \\
\hline total terpenes $(\mu g / L)$ & 26 & 27 & 30 & 34 & 25 \\
\hline benzyl alcohol $(\mu \mathrm{g} / \mathrm{L})$ & $7 \pm 1^{\mathrm{a}}$ & $9 \pm 0^{\mathrm{b}}$ & $12 \pm 1^{\mathrm{d}}$ & $13 \pm 1^{\mathrm{d}}$ & $11 \pm 1^{\mathrm{c}}$ \\
\hline benzaldehyde $(\mu \mathrm{g} / \mathrm{L})$ & $2 \pm 0^{\mathrm{a}}$ & $2 \pm 0^{\mathrm{a}}$ & $2 \pm 0^{\mathrm{a}}$ & $3 \pm 0^{\mathrm{b}}$ & $2 \pm 0^{\mathrm{a}}$ \\
\hline$\beta$-ionone $(\mu \mathrm{g} / \mathrm{L})$ & n.d. & n.d. & n.d. & n.d. & n.d. \\
\hline$\gamma$-butyrolactone $(\mu \mathrm{g} / \mathrm{L})$ & $1250 \pm 35^{b}$ & $1266 \pm 105^{b}$ & $1323 \pm 46^{\mathrm{b}}$ & $1832 \pm 23^{c}$ & $1059 \pm 43^{\mathrm{a}}$ \\
\hline
\end{tabular}

n.d. $=$ not detected.

*All data present mean value \pm standard deviation $(\mathrm{n}=3)$.

Significant differences between procedures are indicated a, b, c, d, e at $\mathrm{p} \leq 0.05$. 
TABLE 4

Concentrations of individual aromatic compounds in the Malvasia Istriana wines produced by different procedures (K-control without skin contact, B6 or B12-addition of $6 \%$ or $12 \%$ grape berries during alcoholic fermentation, Fp-freezing of the pomace, Fg-freezing of whole grapes).

\begin{tabular}{|c|c|c|c|c|c|}
\hline Aromatic compounds & $\mathbf{K}$ & B6 & B12 & Fp & Fg \\
\hline ethyl acetate $(\mathrm{mg} / \mathrm{L})$ & $26.9 \pm 0.7^{\mathrm{b} *}$ & $26.9 \pm 1.6^{\mathrm{b}}$ & $29.2 \pm 0.8^{b}$ & $17.6 \pm 1.0^{\mathrm{a}}$ & $27.3 \pm 3.9^{b}$ \\
\hline 2-butanol (mg/L) & n.d. & n.d. & n.d. & n.d. & n.d. \\
\hline 1-propanol (mg/L) & $17.7 \pm 2.3^{\mathrm{b}}$ & $15.0 \pm 1.3^{\mathrm{ab}}$ & $16.5 \pm 4.2^{\mathrm{ab}}$ & $13.2 \pm 0.8^{\mathrm{a}}$ & $19.1 \pm 1.6^{\mathrm{b}}$ \\
\hline 2-methyl propanol (mg/L) & $25.5 \pm 1.0^{c}$ & $21.1 \pm 1.1^{\mathrm{b}}$ & $19.2 \pm 0.2^{b}$ & $28.0 \pm 0.7^{\mathrm{d}}$ & $14.4 \pm 2.7^{\mathrm{a}}$ \\
\hline 1-butanol (mg/L) & n.d. & n.d. & n.d. & n.d. & n.d. \\
\hline 2-methyl butanol (mg/L) & $46.0 \pm 0.7^{\mathrm{a}}$ & $43.3 \pm 1.7^{\mathrm{a}}$ & $44.1 \pm 3.2^{\mathrm{a}}$ & $55.6 \pm 0.6^{\mathrm{b}}$ & $44.5 \pm 1.8^{\mathrm{a}}$ \\
\hline 3-methyl butanol (mg/L) & $178.2 \pm 6.1^{\mathrm{c}}$ & $167.9 \pm 6.7^{b}$ & $166.1 \pm 1.7^{\mathrm{b}}$ & $201.0 \pm 2.6^{\mathrm{d}}$ & $155.1 \pm 2.9^{a}$ \\
\hline 2-phenylethanol (mg/L) & $36.7 \pm 1.0^{c}$ & $33.1 \pm 0.7^{\mathrm{ab}}$ & $35.9 \pm 2.8^{\mathrm{bc}}$ & $36.6 \pm 0.8^{\mathrm{c}}$ & $32.4 \pm 1.2^{\mathrm{a}}$ \\
\hline total higher alcohols $(\mathrm{mg} / \mathrm{L})$ & 304.1 & 280.4 & 281.8 & 334.4 & 265.5 \\
\hline ethyl butanoate $(\mu \mathrm{g} / \mathrm{L})$ & $214 \pm 7^{\mathrm{bc}}$ & $239 \pm 4^{\mathrm{cd}}$ & $260 \pm 31^{\mathrm{d}}$ & $140 \pm 3^{\mathrm{a}}$ & $209 \pm 14^{\mathrm{b}}$ \\
\hline ethyl hexanoate $(\mu \mathrm{g} / \mathrm{L})$ & $532 \pm 23^{b}$ & $614 \pm 32^{\mathrm{bc}}$ & $619 \pm 85^{\text {bc }}$ & $352 \pm 15^{\mathrm{a}}$ & $643 \pm 58^{c}$ \\
\hline hexyl acetate $(\mu \mathrm{g} / \mathrm{L})$ & $206 \pm 7^{d}$ & $142 \pm 2^{c}$ & $102 \pm 6^{\mathrm{b}}$ & $54 \pm 111^{\mathrm{a}}$ & $291 \pm 15^{\mathrm{e}}$ \\
\hline ethyl lactate $(\mu \mathrm{g} / \mathrm{L})$ & $1466 \pm 71^{\mathrm{d}}$ & $1417 \pm 37^{\mathrm{bc}}$ & $1316 \pm 28^{\mathrm{bc}}$ & $1182 \pm 152^{\mathrm{ab}}$ & $1084 \pm 42^{\mathrm{a}}$ \\
\hline ethyl octanoate $(\mu \mathrm{g} / \mathrm{L})$ & $623 \pm 14^{\mathrm{b}}$ & $636 \pm 18^{\mathrm{b}}$ & $658 \pm 62^{\mathrm{b}}$ & $482 \pm 26^{\mathrm{a}}$ & $691 \pm 96^{\mathrm{b}}$ \\
\hline ethyl decanoate $(\mu \mathrm{g} / \mathrm{L})$ & $239 \pm 7^{b}$ & $227 \pm 3^{b}$ & $180 \pm 30^{\mathrm{a}}$ & $183 \pm 11^{\mathrm{a}}$ & $309 \pm 35^{c}$ \\
\hline diethyl succinate $(\mu \mathrm{g} / \mathrm{L})$ & $82 \pm 1^{\mathrm{ab}}$ & $90 \pm 4^{\mathrm{cd}}$ & $96 \pm 5^{\mathrm{d}}$ & $87 \pm 3^{\mathrm{bc}}$ & $76 \pm 5^{\mathrm{a}}$ \\
\hline ethyl dodecanoate $(\mu \mathrm{g} / \mathrm{L})$ & $23 \pm 2^{\mathrm{bc}}$ & $21 \pm 1^{\mathrm{ab}}$ & $18 \pm 4^{\mathrm{ab}}$ & $18 \pm 0^{\mathrm{a}}$ & $26 \pm 3^{c}$ \\
\hline ethyl cinammate $(\mu \mathrm{g} / \mathrm{L})$ & n.d. & n.d. & n.d. & n.d. & n.d. \\
\hline ethyl hexadecanoate $(\mu \mathrm{g} / \mathrm{L})$ & $11 \pm 1^{\mathrm{a}}$ & $11 \pm 2^{\mathrm{a}}$ & $11 \pm 1^{\mathrm{a}}$ & $14 \pm 1^{\mathrm{b}}$ & $15 \pm 2^{b}$ \\
\hline isoamyl acetate $(\mu \mathrm{g} / \mathrm{L})$ & $1825 \pm 110^{\mathrm{b}}$ & $1948 \pm 59^{\mathrm{bc}}$ & $2136 \pm 240^{c}$ & $1070 \pm 15^{\mathrm{a}}$ & $1952 \pm 161^{\text {bc }}$ \\
\hline 2-phenylethyl acetate $(\mu \mathrm{g} / \mathrm{L})$ & $190 \pm 9^{c}$ & $159 \pm 7^{b}$ & $146 \pm 12^{b}$ & $116 \pm 1^{\mathrm{a}}$ & $195 \pm 16^{c}$ \\
\hline total esters $(\mu g / L)$ & 5411 & 5504 & 5542 & 3698 & 5491 \\
\hline 1-hexanol $(\mu \mathrm{g} / \mathrm{L})$ & $1212 \pm 30^{c}$ & $1221 \pm 28^{c}$ & $1105 \pm 37^{b}$ & $689 \pm 35^{\mathrm{a}}$ & $1446 \pm 21^{\mathrm{d}}$ \\
\hline cis-3-hexen-1-ol ( $\mu \mathrm{g} / \mathrm{L})$ & $32 \pm 1^{\mathrm{b}}$ & $31 \pm 0^{\mathrm{b}}$ & $29 \pm 1^{b}$ & $26 \pm 2^{\mathrm{a}}$ & $93 \pm 2^{\mathrm{c}}$ \\
\hline trans-2-hexen-1-ol $(\mu \mathrm{g} / \mathrm{L})$ & n.d. & n.d. & n.d. & n.d. & n.d. \\
\hline total $C_{6}$ volatiles $(\mu g / L)$ & 1244 & 1252 & 1134 & 715 & 1539 \\
\hline 4-vinylphenol $(\mu \mathrm{g} / \mathrm{L})$ & $67 \pm 1^{\mathrm{a}}$ & $89 \pm 12^{b}$ & $83 \pm 8^{b}$ & $132 \pm 5^{\mathrm{c}}$ & $78 \pm 0^{\mathrm{ab}}$ \\
\hline 4-ethylguaiacol $(\mu \mathrm{g} / \mathrm{L})$ & n.d. & n.d. & n.d. & n.d. & n.d. \\
\hline 4-vinylguaiacol $(\mu \mathrm{g} / \mathrm{L})$ & $379 \pm 11^{\mathrm{b}}$ & $449 \pm 28^{c}$ & $425 \pm 55^{\text {bc }}$ & $296 \pm 29^{a}$ & $518 \pm 4^{\mathrm{d}}$ \\
\hline total volatile phenols $(\mu \mathrm{g} / \mathrm{L})$ & 446 & 538 & 508 & 428 & 596 \\
\hline linalool $(\mu \mathrm{g} / \mathrm{L})$ & $24 \pm 3^{\mathrm{a}}$ & $33 \pm 3^{b}$ & $41 \pm 3^{c}$ & $37 \pm 3^{\mathrm{bc}}$ & $41 \pm 3^{\mathrm{c}}$ \\
\hline$\alpha$-terpineol $(\mu \mathrm{g} / \mathrm{L})$ & n.d. ${ }^{\mathrm{a}}$ & $52 \pm 4^{b}$ & $74 \pm 5^{\mathrm{c}}$ & $78 \pm 13^{\mathrm{cd}}$ & $87 \pm 6^{\mathrm{d}}$ \\
\hline citronellol $(\mu \mathrm{g} / \mathrm{L})$ & $25 \pm 4^{\mathrm{a}}$ & $27 \pm 7^{\mathrm{a}}$ & $31 \pm 3^{\mathrm{a}}$ & $29 \pm 7^{\mathrm{a}}$ & $28 \pm 6^{\mathrm{a}}$ \\
\hline $\operatorname{nerol}(\mu \mathrm{g} / \mathrm{L})$ & n.d. & n.d. & n.d. & n.d. & n.d. \\
\hline geraniol $(\mu \mathrm{g} / \mathrm{L})$ & n.d. & n.d. & n.d. & n.d. & n.d. \\
\hline total terpenes $(\mu g / L)$ & 49 & 112 & 146 & 144 & 156 \\
\hline benzyl alcohol $(\mu \mathrm{g} / \mathrm{L})$ & $5 \pm 1^{\mathrm{a}}$ & $9 \pm 1^{\mathrm{b}}$ & $12 \pm 1^{\mathrm{c}}$ & $14 \pm 1^{\mathrm{d}}$ & $14 \pm 1^{\mathrm{d}}$ \\
\hline benzaldehyde $(\mu \mathrm{g} / \mathrm{L})$ & $1 \pm 0^{\mathrm{a}}$ & $1 \pm 0^{\mathrm{a}}$ & $1 \pm 0^{\mathrm{a}}$ & $1 \pm 0^{\mathrm{a}}$ & $1 \pm 0^{\mathrm{a}}$ \\
\hline$\beta$-ionone $(\mu \mathrm{g} / \mathrm{L})$ & n.d. & n.d. & n.d. & n.d. & n.d. \\
\hline$\gamma$-butyrolactone $(\mu \mathrm{g} / \mathrm{L})$ & $1396 \pm 57^{\mathrm{a}}$ & $1616 \pm 9^{b}$ & $1725 \pm 96^{b}$ & $2094 \pm 77^{c}$ & $1372 \pm 88^{\mathrm{a}}$ \\
\hline
\end{tabular}

n.d. = not detected.

*All data present mean value \pm standard deviation $(n=3)$.

Significant differences between procedures are indicated $a, b, c, d$, e at $p \leq 0.05$. 
TABLE 5

Aromatic compounds with OAV $>1$ detected in the Zelen, Ribolla Gialla and Malvasia Istriana wines, odour thresholds, odour description and assignation of compounds to different odorant series.

\begin{tabular}{|c|c|c|c|}
\hline Aromatic compound & Odour threshold & Odour description & Odorant series \\
\hline 2-methyl propanol & $40 \mathrm{mg} / \mathrm{L} *$ & alcohol, wine like, nail polish & solvent \\
\hline 3-methyl butanol & $30 \mathrm{mg} / \mathrm{L} *$ & alcohol, solvent, nail polish & solvent \\
\hline 2-phenylethanol & $10 \mathrm{mg} / \mathrm{L} * \dagger$ & rose, honey & floral \\
\hline ethyl acetate & $15 \mathrm{mg} / \mathrm{L} \dagger$ & $\begin{array}{l}\text { solvent, fruity, pineapple, } \\
\text { varnish }\end{array}$ & solvent, fruity \\
\hline ethyl butnaoate & $20 \mu \mathrm{g} / \mathrm{L} \ddagger$ & banana, pineapple, strawberry & fruity \\
\hline ethyl hexanoate & $5 \mu \mathrm{g} / \mathrm{L} * \dagger$ & fruity, green apple, banana & fruity \\
\hline ethyl octanoate & $580 \mu \mathrm{g} / \mathrm{L} \bullet$ & fruity, banana, sweet, pear & fruity, fatty \\
\hline isoamyl acetate & $30 \mu \mathrm{g} / \mathrm{L} *$ & banana, fruity, sweet & fruity \\
\hline 2-phenylethyl acetate & $250 \mu \mathrm{g} / \mathrm{L} *$ & flowery & floral \\
\hline 1-hexanol & $1300 \mu \mathrm{g} / \mathrm{L} \dagger$ & herbaceous, green, woody & green \\
\hline 4-vinyl guaiacol & $440 \mu \mathrm{g} / \mathrm{L} \square$ & $\begin{array}{l}\text { black pepper, clove-like, } \\
\text { smoky }\end{array}$ & phenolic-spicy \\
\hline linalool & $15 \mu \mathrm{g} / \mathrm{L} \uparrow$ & flowery, rose, grape-like & floral \\
\hline citronelol & $18 \mu \mathrm{g} / \mathrm{L} \diamond$ & citrus, grapefruit, flowery & floral \\
\hline
\end{tabular}

TABLE 6

Overall OAV of each odorant series for Zelen, Ribolla Gialla and Malvasia Istriana (K-control without skin contact, B6 or B12addition of $6 \%$ or $12 \%$ grape berries during alcoholic fermentation, Fp-freezing of the pomace, Fg-freezing of whole grapes).

\begin{tabular}{|c|c|c|c|c|c|}
\hline ZELEN & $\mathbf{K}$ & B6 & B12 & Fp & Fg \\
\hline fruity & $138.1 \pm 2.1^{\mathrm{b} *}$ & $133.8 \pm 9.1^{\mathrm{b}}$ & $151.6 \pm 5.5^{\mathrm{c}}$ & $93.2 \pm 3.8^{\mathrm{a}}$ & $132.9 \pm 1.7^{\mathrm{b}}$ \\
\hline floral & $7.7 \pm 0.2^{\mathrm{a}}$ & $8.3 \pm 0.2^{b}$ & $9.0 \pm 0.2^{\mathrm{c}}$ & $10.4 \pm 0.4^{\mathrm{d}}$ & $10.6 \pm 0.4^{\mathrm{d}}$ \\
\hline solvent & $8.4 \pm 0.1^{b}$ & $9.4 \pm 0.1^{\mathrm{c}}$ & $8.3 \pm 0.0^{\mathrm{b}}$ & $7.5 \pm 0.1^{\mathrm{a}}$ & $7.7 \pm 0.1^{\mathrm{a}}$ \\
\hline green & n.d. ${ }^{\mathrm{a}}$ & n.d. ${ }^{\mathrm{a}}$ & n.d. ${ }^{\mathrm{a}}$ & n.d. ${ }^{\mathrm{a}}$ & $1.5 \pm 0.0^{\mathrm{b}}$ \\
\hline fatty & n.d. & n.d. & n.d. & n.d. & n.d. \\
\hline phenolic-spicy & $2.0 \pm 0.3^{\mathrm{ab}}$ & $2.4 \pm 0.1^{\mathrm{ab}}$ & $2.6 \pm 0.2^{b}$ & $2.0 \pm 0.8^{\mathrm{a}}$ & $2.4 \pm 0.1^{\mathrm{ab}}$ \\
\hline RIBOLLA G. & $\mathbf{K}$ & B6 & B12 & $\mathbf{F p}$ & Fg \\
\hline fruity & $307.3 \pm 33.5^{b}$ & $332.8 \pm 13.5^{\mathrm{bc}}$ & $357.6 \pm 12.4^{c}$ & $210.9 \pm 4.5^{\mathrm{a}}$ & $342.2 \pm 21.4^{b c}$ \\
\hline floral & $6.4 \pm 0.2^{b}$ & $5.6 \pm 0.3^{\mathrm{a}}$ & $5.5 \pm 0.3^{\mathrm{a}}$ & $5.7 \pm 0.4^{\mathrm{a}}$ & $5.5 \pm 0.2^{\mathrm{a}}$ \\
\hline solvent & $8.5 \pm 0.3^{b}$ & $8.4 \pm 0.1^{b}$ & $8.4 \pm 0.2^{b}$ & $7.5 \pm 0.3^{\mathrm{a}}$ & $7.8 \pm 0.1^{\mathrm{a}}$ \\
\hline green & n.d. & n.d. & n.d. & n.d. & n.d. \\
\hline fatty & $1.6 \pm 0.2^{\mathrm{bc}}$ & $1.5 \pm 0.1^{\mathrm{b}}$ & $1.6 \pm 0.0^{\mathrm{bc}}$ & $1.3 \pm 0.0^{\mathrm{a}}$ & $1.7 \pm 0.1^{\mathrm{c}}$ \\
\hline phenolic-spicy & $1.2 \pm 0.0^{\mathrm{a}}$ & $1.2 \pm 0.0^{\mathrm{a}}$ & $1.2 \pm 0.0^{\mathrm{a}}$ & $1.5 \pm 0.1^{\mathrm{c}}$ & $1.3 \pm 0.1^{\mathrm{b}}$ \\
\hline MALVASIA I. & $\mathbf{K}$ & B6 & B12 & Fp & Fg \\
\hline fruity & $180.7 \pm 8.5^{\mathrm{b}}$ & $202.5 \pm 5.6^{\mathrm{bc}}$ & $211.1 \pm 26.4^{\mathrm{c}}$ & $115.1 \pm 3.6^{a}$ & $207.2 \pm 17.5^{\mathrm{bc}}$ \\
\hline floral & $6.7 \pm 0.3^{\mathrm{a}}$ & $7.0 \pm 0.6^{\mathrm{ab}}$ & $8.1 \pm 0.2^{\mathrm{c}}$ & $7.7 \pm 0.3^{\mathrm{bc}}$ & $7.6 \pm 0.6^{\mathrm{bc}}$ \\
\hline solvent & $7.7 \pm 0.2^{\mathrm{bc}}$ & $7.4 \pm 0.3^{\mathrm{ab}}$ & $7.5 \pm 0.1^{\mathrm{bc}}$ & $7.9 \pm 0.0^{\mathrm{c}}$ & $7.0 \pm 0.4^{\mathrm{a}}$ \\
\hline green & n.d. ${ }^{\mathrm{a}}$ & n.d. ${ }^{\mathrm{a}}$ & n.d. ${ }^{\mathrm{a}}$ & n.d. ${ }^{\mathrm{a}}$ & $1.1 \pm 0.0^{\mathrm{b}}$ \\
\hline fatty & $1.1 \pm 0.2^{b}$ & $1.1 \pm 0.0^{b}$ & $1.1 \pm 0.1^{\mathrm{b}}$ & $0.0 \pm 0.0^{\mathrm{a}}$ & $1.2 \pm 0.2^{b}$ \\
\hline phenolic-spicy & n.d. ${ }^{a}$ & $1.1 \pm 0.1^{\mathrm{b}}$ & n.d. ${ }^{a}$ & n.d. ${ }^{a}$ & $1.2 \pm 0.0^{\mathrm{c}}$ \\
\hline
\end{tabular}

n.d. $=$ not detected.

*All data present mean value \pm standard deviation $(\mathrm{n}=3)$.

Significant differences between procedures are indicated a, b, c, d at $\mathrm{p} \leq 0.05$. 


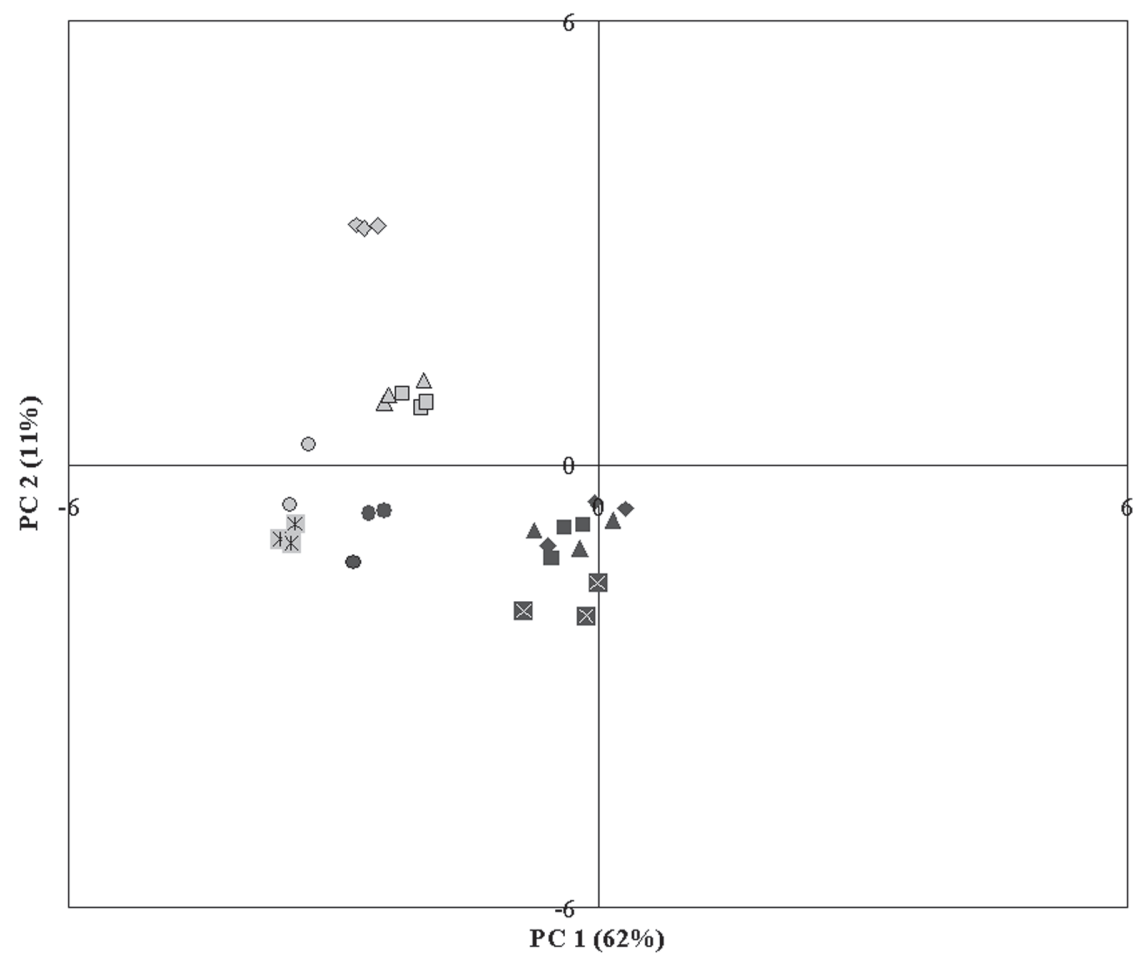

FIGURE 1

PCA performed on the OAV of aromatic compounds found in Zelen and Malvasia Istriana wines produced by different procedures in the plane defined by the first two main components (control without skin contact $-\square$, addition of $6 \%$ grape berries during alcoholic fermentation $-\diamond$, addition of $12 \%$ grape berries during alcoholic fermentation $-\triangle$, freezing of the pomace $-\bigcirc$, freezing of whole grapes - ; ; Zelen - grey signs, Malvasia Istriana - black signs).

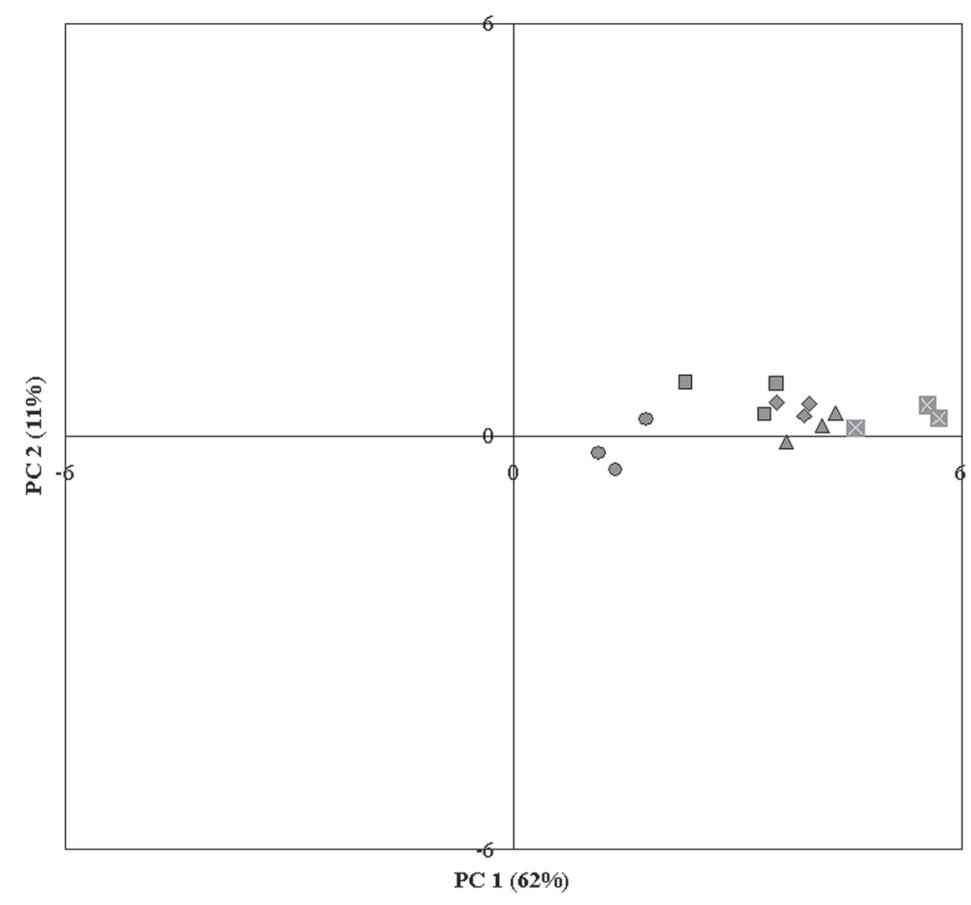

FIGURE 2

PCA performed on the OAV of aromatic compounds found in Ribolla Gialla wines produced by different procedures in the plane defined by the first two main components (control without skin contact $-\square$, addition of $6 \%$ grape berries during alcoholic fermentation $-\diamond$, addition of $12 \%$ grape berries during alcoholic fermentation $-\triangle$, freezing of the pomace $-\bigcirc$, freezing of whole grapes $-\bigotimes)$. 


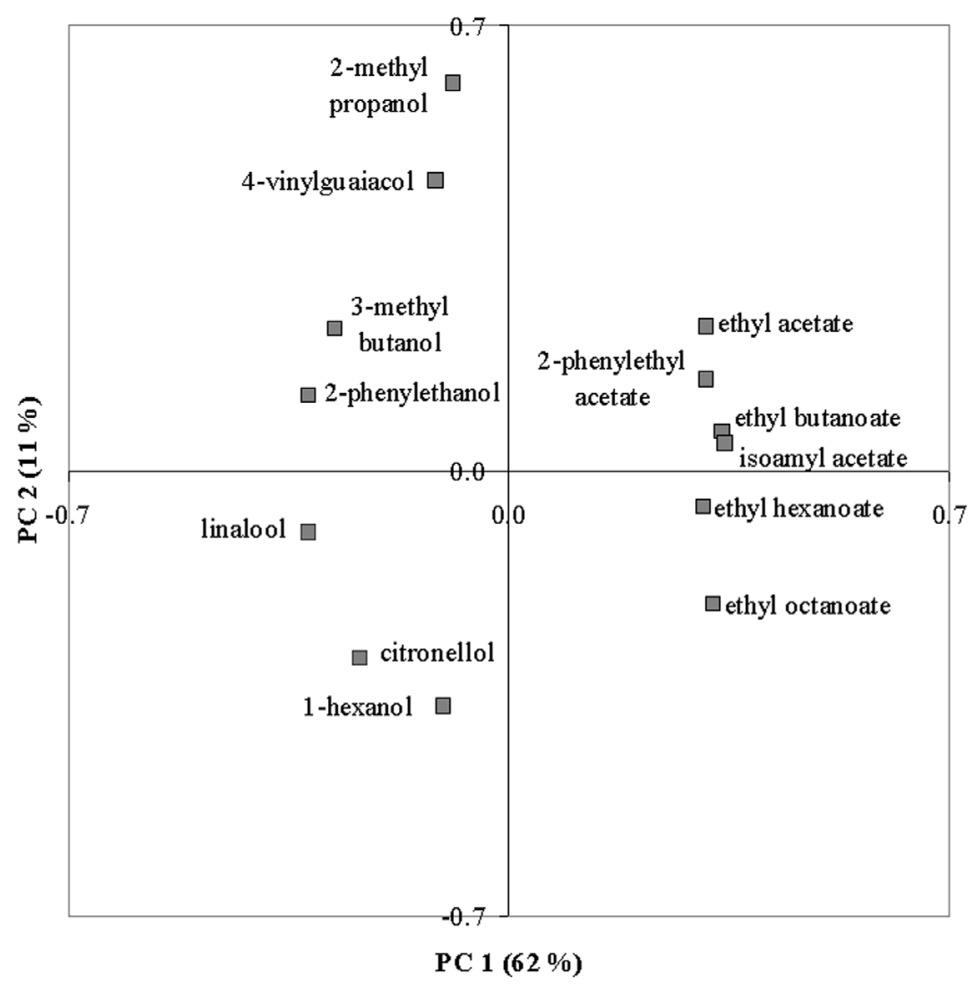

FIGURE 3

PCA performed on the OAV of aromatic compounds found in Zelen, Ribolla Gialla and Malvasia Istriana wines in the plane defined by the first two main components.

Aromatic compounds found in the Zelen wines with OAV >1 were: 2-methyl propanol, 3-methyl butanol, 2-phenylethanol, ethyl acetate, ethyl butanoate, ethyl hexanoate, isoamyl acetate, 1-hexanol, 4-vinylguaiacol, linalool and citronellol. Aromatic compounds found in the Ribolla Gialla wines with OAV $>1$ were: 3-methyl butanol, 2-phenylethanol, ethyl acetate, ethyl butanoate, ethyl hexanoate, ethyl octanoate, 2-phenylethyl acetate, isoamyl acetate, 4-vinylguaiacol and citronellol. Aromatic compounds found in the Malvasia Istriana wines with OAV $>1$ were: 3-methyl butanol, 2-phenylethanol, ethyl acetate, ethyl butanoate, ethyl hexanoate, ethyl octanoate, isoamyl acetate, 1-hexanol, 4-vinylguaiacol, linalool and citronellol.

In Table 5 each aromatic compound was assigned to one or two odorant series, depending on its principal odour descriptors. The floral, fruity, solvent, green, fatty and phenolic-spicy were chosen for this purpose on account of their usefulness for describing and distinguishing young fresh and fruity wines (Peinado et al., 2004; Sanchez Palomo et al., 2007). By combining the OAV for each individual compound in an odorant series, the overall OAV for each series was obtained (Table 6). The results were subjected to MANOVA in order to identify which series exhibited significant differences between procedures within each variety.

From Table 6 it is obvious that fruity odour dominated in all three varieties. The main reason was the high concentration of the so-called fruity esters in young wines after alcoholic fermentations. Those compounds, acetates, short chain and medium chain esters play a significant role in the properties of young white wines made from neutral grape varieties (Ferreira et al., 1995). In combination with their relative low odour thresholds, the most important odorants in this series were ethyl hexanoate, isoamyl acetate and ethyl butanoate. Significantly $(\mathrm{p} \leq 0.05)$ higher fruitiness in the case of all three varieties was determined in the B12 process and the lowest one in the Fp process.

Floral odour in Zelen and Malvasia Istriana correlated with terpene concentrations. Terpene compounds typical for aromatic varieties such as Muscat, have a low odour threshold and are generally associated with floral and citric aromas (Etievant et al., 1983; Guth, 1997). B12, Fp and Fg proved to be the most successful processes for the extraction of those grape derived volatiles. On the other hand, in Ribolla Gialla because of its low terpene content, fermentative volatiles 2-phenylethanol, 2-phenylethyl acetate and ethyl acetate were determinative for floral odour. Significantly higher floral overall OAVs for Ribolla Gialla were determined only in the $\mathrm{K}$ procedure.

Solvent odour mainly correlated with the higher alcohol 2-methyl propanol and 3-methyl butanol content and less with ethyl acetate. As mentioned previously, generally lower concentrations of total higher alcohols were determined in macerated wines in correlation with some data (Sanchez Palomo et al., 2007). This effect was not detected for other varieties or maceration procedures by some authors (Tamborra et al., 1992; Cabaroglu et al., 1997; Peinado et al., 2004; Selli et al., 2006). As reported previously, higher concentrations of total higher alcohols are not desired when combined with lower ester content (Ferreira et al., 1995; 
Lukic et al., 2008). For Zelen and Ribolla Gialla the solvent odour had significantly less impact in Fp and Fg compared to $\mathrm{K}$, for Malvasia Istriana only Fg produced the same effect.

Green odour was correlated to $\mathrm{C}_{6}$ alcohol 1-hexanol. Higher concentrations of $\mathrm{C}_{6}$ alcohols and aldehydes in wines are generally not desired because of the intensive herbaceousgreen odour dominant in wines made from unripe grapes, but in small quantities they can give fresh and green notes to neutral varieties (Sanchez Palomo et al., 2006, 2007). Bearing this in mind, the concentrations of 1-hexanol above the odour threshold in the Fg process for Zelen and Malvasia Istriana can be accepted as positive because of the additional freshness and complexity in wine odour.

In this study, fatty odour correlated with ethyl octanoate, as other compounds with similar impact, like ethyl lactate or cis-3-hexen-1-ol, and were not present in the concentrations above odour thresholds (Peinado et al., 2004). The lowest impact of this odour series was determined in the Fp procedure only for Ribolla Gialla and Malvasia Istriana, but the actual differences were rather low.

Phenolic-spicy odour correlated with volatile phenols. Volatile phenols are considered characteristic components of wine aroma, but their influence on wine can be positive or negative depending on their final concentration. 4-vinylphenol in the concentration above $725 \mu \mathrm{g} / \mathrm{L}$ is considered as off-flavour (Chatonnet et al., 1992, 1993). In this case only 4-vinylguaiacol, associated with positive black pepper, clove-like, smoky odours, had the concentrations above odour threshold (Versini, 1985; Marais \& Rapp, 1988; Rocha et al., 2005). The highest impact of phenolicspicy odour series was detected in macerated wines, in B12 for Zelen, in Fp for Ribolla Gialla and in Fg for Malvasia Istriana. In our experiment volatile phenols did not attain levels sufficient to produce off-flavours. They were understood to be similar to $\mathrm{C}_{6}$ compounds like volatiles that can add additional complexity to wine odour.

\section{Sensory evaluation}

For sensory evaluation wines were compared in the first $(\mathrm{K}$, B6, B12) and the second group (K, Fp, Fg). In the first group for Zelen odour in B12 and overall impression in B6 were rated as the most preferable. In the second group for Zelen, odour in $\mathrm{K}$ and overall impression in Fp were prefered. In the first group for Ribolla Gialla, odour in $\mathrm{K}$ and overall impression in B12 were rated as preferable. In the second group for Ribolla Gialla, odour and overall impression in Fg were chosen as the best. In the first group for Malvasia Istriana, odour in B12 and overall impression in B6 were rated as preferable. In the second group for Malvasia Istriana, odour in $\mathrm{K}$ and $\mathrm{Fg}$ rated equally high, but for overall impression Fg was chosen. In conclusion, odour evaluation differences in the various processes were probably more difficult to detect because of the dominancy of fruity odour, but for overall impression the skin contact wines were always the most preferred.

\section{Principal component analysis}

To evaluate the influence of some aromatic compounds and the differentiation between varieties or wine-making procedures, the OAV $>1$ were subjected to a principal component analysis (PCA). Final results are presented in Fig. 1, Fig. 2 and Fig. 3. The two first components (PC 1, PC 2) explained $73 \%$ of the overall variance, with PC 1 accumulating $>62 \%$. Together with the third and fourth PC they explained $86 \%$ of the overall variance. Fig. 1 and Fig. 2 show the position of the wine samples according to their values on the two principal components. As can be seen in Fig. 1, PC 1 separated Malvasia Istriana from Zelen var. with the exception of the Malvasia Istriana Fp wines. PC 2 was effective for the separation between $\mathrm{Fg}, \mathrm{K}$ and $\mathrm{B} 6$ procedure in Zelen. For the Ribolla Gialla variety in Fig. 2, PC 1 distinguished between Fp and Fg procedures.

The influences of individual aromatic compounds are presented in Fig. 3. Variables mostly contributing to PC 1 were ethyl butanoate, isoamyl acetate, ethyl hexanoate and 2-phenylethyl acetate. These variables were negatively correlated with 2-phenyl ethanol and linalool, lying near PC 1 on the opposite side. Variables mostly contributing to PC 2 were 4-vinylguaiacol and 2-methyl propanol.

\section{CONCLUSIONS}

Alternative maceration procedures proved to have an effect on both general wine and aromatic compound composition. General wine composition were more affected by freezing (Fp, Fg) than by the addition of berries (B6, B12), when compared to the control procedures. After revising the aromatic compound data it seems that the procedures B12 and $\mathrm{Fg}$ can be accepted as promising for the production of young, fresh Zelen and Malvasia Istriana wines. Based on analytical data, those procedures resulted in wines with more pronounced fruity (B12) and floral odours (B12, Fg), less intensive solvent odours (Fg) and additional freshness (Fg). For the same procedures in Ribolla Gialla, only additional fruitiness (B12) and less intensive solvent odour (Fg) were beneficial towards the control process $\mathrm{K}$. In correlation with the lower concentrations of terpenes determined in this variety, maceration processes examined in this experiment had little influence on floral odour in the Ribolla Gialla wines. In the sensorial evaluation the skin contacted wines were preferred to the control wines. Applications of the same skin contact processes to some aromatic varieties could provoke even more pronounced changes in the aroma composition due to higher concentrations of grape derived aromatics.

\section{LITERATURE CITED}

Arnold, R.A. \& Noble, A.C., 1979. Effect of pomace contact on the flavor of Chardonnay wine. Am. J. Enol. Vitic. 30(3), 179-181.

Aryan, A.P., Wilson, B., Strauss, C.R. \& Williams, P.J., 1987. The proprietes of glycosidases of Vitis vinifera and comparison of their $\beta$-glucosidases activity with that of exogenus enzymes. An assessment of possible applications in enology. Am. J. Enol. Vitic. 38(3), 182-188.

Bayonove, C., Gunata, Z., Sapis, J.C., Baumes, R.L., Dugelay, I. \& Grassin, C., 1993. L' aumento degli aromi nel vino mediante l' uso degli enzimi. Vignevini 10(9), 33-36.

Benard, P., Bourzeix, M., Buret,M., Flanzy,C. \& Mourgues J., 1971. Methode de vinification par maceration carbonique. Ann. Technol. Agric. 20(2-3), 199-215. 
Bitteur, S., Tesniere, C., Fauconnet, A., Bayonove, C. \& Flanzy C., 1996. Carbonic anaerobiosis of Muscat grape. 2. Changes in the distribution of free and bound terpenols. Sci. Aliment. 16(1), 37-48.

Bitteur, S., Tesniere, C., Sarris, J., Baumes, R., Bayonove, C. \& Flanzy, C., 1992. Carbonic anaerobiosis of Muscat grape. I. Changes un the profiles of free and bound volatiles. Am. J. Enol. Vitic. 43(1), 41-48.

Cabaroglu, T., Canbas, A., Baumes, R., Bayonove, C., Lepoutre, J.P. \& Gunata, Z., 1997. Aroma composition of white wine of Vitis vinifera L. cv. Emir as affected by skin contact. J. Food Sci. 62(4), 680-683.

Cabrita, M.J., Costa Freitas, A.M., Laureano, O. \& Di Stefano, R., 2006. Glycosidic aroma compounds of some Portuguese grape cultivars. J. Sci. Food Agric. 86(6), 922-931.

Chatonnet, P., Dubourdieu, D., Boidron, J.N. \& Pons, M. 1992. The origins of ethylphenols in wine. J. Sci. Food Agric. 60(2), 165-178.

Chatonnet, P., Dubourdieu, D., Boidron, J.N. \& Lavigne, V. 1993. Synthesis of volatile phenols by Saccharomyces cerevisiae in wines. J. Sci. Food Agric. 62(2), 191-202.

Chavez, M., Zea, L., Moyano, L. \& Medina, M., 2007. Changes in color and odorant compounds during oxidative aging of Pedro Ximenez sweet wines. J. Agric. Food Chem. 55(9), 3592-3598.

Delcroix, A., Gunata, Z., Sapis, J.S., Salmon, J.M. \& Bayonove, C., 1994. Glycosidase activites of three enological yeast strains during winemaking: Effect on the terpenol content of muscat wine. Am. J. Enol. Vitic. 45(3), 291-296.

EEC, 1990. Commission regulation (EEC), N. 2676/90 of 17. September 1990 determining Community methods for the analysis of wines. 1990. Off J. Eur. Communities L 272, 1-129.

Etievant, P.X., Issanchou, S.N. \& Bayonove, C. L. 1983. The flavour of Muscat wine: The sensory contribution of some volatile compounds. J. Sci. Food Agric. 34(5), 497-504.

Ferreira, V., Fernardez, P., Pena, C., Escudero, A. \& Cacho, J.F. 1995. Investigation of the role played by fermentation esters in the aroma of young Spanish wines by multivariate analysis. J. Sci. Food Agric. 67(3), 381-392.

Gerbi, V., Zeppa, G., Manara, C. \& Minati, J.L., 1991. Esperienze di macerazionea freddo con uve Moscato. L' Enotecnico 27(12), 57-66.

Gunata, Y.Z., Baynove, C., Baumes, R. \& Cordonnier, R., 1985. The aroma of grapes I. Extraction and determination of free and glicosidically bound fractions of some grape components. J. Chromatogr. A 331(1), 83-90.

Guth H., 1997. Quantitation and sensory studies of character impact odorants on different white wine varieties. J. Agric. Food Chem. 45(8), 3027-3032

Jackson R.S., 2009 ( $2^{\text {nd }}$ ed). Wine Tasting. A Professional Handbook. Academic Press, San Diego.

Kovacevic Ganic, K., Persuric, D., Gluhic, D., Banovic, M., Komes, D., Gracin, L. \& Lovric, T., 2005. Aroma precursors of Malvasia Istriana Istriana wine. Riv. Vitic. Enol. 58(2-4), 99-108.

Lukic, I., Plavsa, T., Sladonija, B., Radeka, S. \& Persuric, D., 2008. Aroma compounds as markers of wine quality in the case of Malvazija Istarska young wine. J. Food Qual. 31(6), 717-735.

Marais, J.S., 1987. Terpenes in grape juice and wine: Effect of heat treatment and skin contact. In: Charalambous G. (ed.). Proc. $5^{\text {th }}$ Intern. Flavor Conf., July 1997, Porto Karras, Greece. pp. 783-798.

Marais, J. \& Rapp, A., 1988. Effect of skin contact time and temperature on juice and wine composition and wine quality. S. Afr. J. Enol.Vitic. 9(1), 22-30.

Mateo, J.J. \& Jimenez, M., 2000. Monoterpenes in grape juice and wines. J. Chromatogr. A 881(1-2), 557-567.
Moio, L., Chambellant, E., Lasschaeve, I., Issanchau, S., Schlich, P. \& Etievant, P.X., 1995. Production of representative wine extracts for chemical and olfactory analysis. Ital. J. Food Sci. 7(3), 265-278.

Moreno, J.A., Zea, L., Moyano, L. \& Medina, M. 2005. Aroma compounds as markers of the changes in sherry wines subjected to biological ageing. Food Control 16(4), 333-338.

Moyano, L., Zea, L., Moreno, J.A. \& Medina, M., 2002. Analytical study of aromatic series in sherry wines subjected to biological ageing. J. Agric Food Chem. 50(25), 7356-7361.

Moyano, L., Zea, L., Villafuerte, L. \& Medina, M., 2009. Comparison of odor-active compounds in sherry wines processed from ecologically and convetionally grown Pedro Ximenez grapes. J. Agric. Food Chem. 57(3), 968-973.

Peinado R.A., Moreno J., Bueno J.E., Moreno J.A. \& Mauricio J.C., 2004. Comparative study of aromatic compounds in two young white wines subjected to pre-fermentative cryomaceration. Food Chem. 84(4), 585-590.

Ramey, D. Bertrand, A., Ough, C.S., Singleton, V.L. \& Sanders, E., 1986. Effects of skin contact temperature on Chardonnay must and wine composition. Am. J. Enol. Vitic. 37(2), 99-106.

Rapp, A. \& Mandrey, H., 1986. Wine aroma. Experientia, 42, 873-884.

Rapp, A. \& Versini, G., 1995. Influence of nitrogen compounds in grapes on compounds in wines. In: Charalambous G. (eds). Food flavour: Generation, analysis and process influence, Amsterdam, Elsevier Science BV. pp. 16591693

Reynolds, A.G., Wardle, D.A. \& Dever M., 1993. Terpene response to pressing, harvest date, skin contact in Vitis vinifera. Hortic. Sci. 28(9), 920924.

Ribéreau Gayon, P., Dubourdieu, D., Doneche, B. \& Lonvaud, A., 2006 $\left(2^{\text {nd }}\right.$ ed). Handbook of Enology. Volume 1. The Microbiology of Wine and Vinifications. John Wiley \& Sons, Chichester.

Rigo, A., Vianello, F., Clementi, G., Rossetto, M., Scarpa, M., Vrhovsek, U., Mattivi, F., 2000. Contribution of proanthocyanidins to the peroxy radical scavenging capacity of some Italian red wines. J. Agric. Food Chem. 48(6), 1996-2002.

Rocha, S.M., Coutinho, P., Delgadillo, I., Cardoso, A.D. \& Coimbra, M.A., 2005. Effect of enzymatic aroma release on the volatile compounds of white wines presenting different aroma potentials. J. Sci. Food Agric. $85(2), 199-205$

Rocha, S. M., Rodrigues, F., Coutinho, P., Delgadillo, I., Cardoso, A.D. \& Coimbra, M.A., 2004. Volatile composition of Baga red wine. Assessment of the identification of the would be impact odorants. Anal. Chim. Acta 513(1), 257-262.

Rodriguez Bencomo, J.J., Mendez Siverio, J.J., Perez Trujillo, J.P. \& Cacho, J., 2008. Effect of skin contact on bound aroma and free volatiles of Listan blanco wine. Food Chem. 110(1), 214-225.

Sanchez Palomo, E., Diaz Hidalgo, M.C., Gonzalez Vinas, M.A. \& Perez Coello, M.S., 2005. Aroma enhancement in wines from different grape varieties using exogenous glycosidases. Food Chem. 92(4), 627-635.

Sanchez Palomo, E., Gonzales Vinas, M.A., Diaz Maroto, M.C., Soriano Perez, A. \& Perez Coello, M.S., 2007. Aroma potential of Albillo wines and effect of skin contact treatment. Food Chem. 103(2), 63-640.

Sanchez Palomo, E., Perez Coello, M.S., Diaz Maroto, M.C., Gonzales Vinas, M.A. \& Cabezudo, M.D., 2006. Contribution of free and glycosidically bound volatile compounds to the aroma of muscat »a petit grains « wines and effect of skin-contact treatment. Food Chem. 95(2), 279-289. 
Sapis, J.C., Caboulet, D., Samson, A. \& Chauvet S., 1995. Le traitement des raisins blancs par supraextraction: incidence sur les caracteristiques et la qualitedes vins. White grapes treatment by supraextraction: effects on characteristics and quality of wine. Rev. Fr. Oenol. 153(35), 55-56.

SAS Software, Version 8.01, 1999. Cary. NC.: SAS Institute Inc.

Schneider, R., Baumes, R.L., Bayonove, C.L. \& Razungles, A., 1998. Volatile components involved in the aroma of sweet fortified wines (vins doux naturels) from Grenache noir. J. Agric. Food Chem. 46(8), 3230-3237.

Selli, S., Cabaroglu, T., Canbas, A., Erten, H. \& Nurgel, C., 2003. Effect of skin contact on the aroma composition of the musts of Vitis vinifera L. cv. Muscat of Boronova and Narice grown in Turkey. Food Chem. 81(3), 341-347.

Selli, S., Canbas, A., Cabaroglu, T., Erten, H. \& Gunata, Z., 2006. Aroma components of cv. Muscat of Bornova wines and influence of skin contact treatment. Food Chem. 94(3), 319-326.

Tamborra, P., 1992. Influenza della macerazione sul contenuto di terpeni liber e glucosidi nel Moscatello selvatico. Riv. Viti. Enol. 65(2), 35-45.
Tamborra, P., Martino, N. \& Esti, M., 2004. Laboratory tests on glycosidase preparations in wine. Anal. Chim. Acta 513(1), 299-303.

Versini, G. 1985. Sull aroma del vino »Traminer aromatico« o »Gewurtztraminer«. Vignevini 12(1-2), 57-65.

Versini, G., Inama, S. \& Sartori, G., 1981. A capillary column gaschromatographic research into the terpene constituents of Riesling Renano (Rhine Riesling) wine from Trentino Alto Adige: Their distribution within berries, their passage into must and their presence in the wine according to different wine-making procedures. Organoleptic considerations. Vini d'Italia 23, 189-211.

Verisni, G. \& Tomasi, T. 1983. Confronto tra i componenti volatili dei vini rossi ottenuti con macerazione tradizionale e macerazione carbonica. Importanza differenziante del cinnamato di etile. L'Enotecnico 19, 595-600.

Williams, P.J., Strauss, C.R. \& Wilson, B., 1981. Classification of the monoterpenoid composition of muscat grapes. Am. J. Enol. Vitic. 32(2), $230-235$. 